Article

\title{
Cooperating to Compete in the Global Air Cargo Industry: The Case of the DHL Express and Lufthansa Cargo A.G. Joint Venture Airline 'AeroLogic'
}

\author{
Glenn Baxter * and Panarat Srisaeng * \\ School of Tourism and Hospitality Management, Suan Dusit University, \\ Huahin Campus 77110, Prachaup Khiri Khan, Thailand \\ * Correspondence: g_glennbax@dusit.ac.th (G.B.); panarat_sri@dusit.ac.th (P.S.); Tel.: +66-32-522508 (P.S.)
}

Received: 28 November 2017; Accepted: 13 March 2018; Published: 16 March 2018

\begin{abstract}
This paper presents a case study of the DHL Express and Lufthansa Cargo strategic joint venture cargo airline 'AeroLogic', the global air cargo industry's largest operative joint venture between an airline and a leading international express and logistics provider. The study used a qualitative research approach. The data gathered for the study was examined by document analysis. The strategic analysis of the AeroLogic joint venture was based on the use of Porter's Five Forces framework. The study found that the AeroLogic joint venture airline has provided synergistic benefits to both partners and has allowed the partners to access new markets and to participate in the evolution of the air cargo industry. The new venture has also enabled both joint venture partners to enhance their competitive position in the global air cargo industry through strengthened service offerings and has provided the partners with increased cargo capacities, a larger route network, and greater frequencies within their own route networks. The study also found that the AeroLogic business model is unique in the air cargo industry. A limitation of the study was that AeroLogic's annual revenue or freight traffic data was not available. It was, therefore, not possible to analyse the business performance of the joint venture.
\end{abstract}

Keywords: air cargo; AeroLogic; case study; DHL Express; freighter aircraft; joint venture; Lufthansa Cargo; route network

\section{Introduction}

In today's highly competitive business environment, to achieve competitive advantage or to survive, many companies have formed strategic linkages with others [1]. The necessity to serve firms with truly global supply chain requirements and distributive infrastructure has helped stimulate the formation of alliances within the global air cargo industry [2-4]. This phenomenon is becoming more prevalent as the growing adoption of supply chain management strategies are resulting in greater integration and cooperation between actors participating in air cargo supply chains [5]. Like airline passenger services, air cargo carriers have started to cooperate through common product/service options, sales and compatible information systems and to develop global networks. Such alliances are partly intended to combat the challenges posed by regulation in the industry, as well as the rapid growth of the integrated carriers, such as FedEx and United Parcel Service (UPS) [6]. These alliances enable the combination of shipment volumes and distribution channel requirements and the ability for the partners to offer consistent time scheduled flights to satisfy customer requirements. The alliances also facilitate joint profit optimization [7]. Moreover, as no single airline could cover all air cargo customers' requirements of its own accord, cooperation and partnerships, therefore, become critical [8].

Despite their growing significance, there are few published papers that have examined strategic joint ventures in the international air cargo industry. The objective of this paper is to examine the development and 
the progress to date of the strategic joint venture all-cargo airline-AeroLogic-between Lufthansa Cargo A.G. and DHL Express, the global air cargo industry's largest and most intensive operating collaboration and partnership between an airline and a leading international express and logistics provider [9]. Additional aims of the paper are to examine how the joint venture airline AeroLogic has enhanced DHL Express and Lufthansa Cargo AG competitive positions in the world air cargo industry, to examine the selection of the AeroLogic freighter aircraft type and the airline's principal operational base, as well as to examine how the AeroLogic route network has evolved over time.

\section{Background}

\subsection{Joint Venture Partnerships}

Businesses form alliances for a variety of strategic reasons [10,11]. Among these, the one central to this paper is the joint venture partnership. According to Ginter et al. [12], a joint venture is the combination of resources by two or more separate firms to accomplish a designated task or objective. Thus, joint ventures are separate entities that are owned jointly by two or more firms and which represent a partial combination of the partner's resources [13]. The emerging entity, the joint venture, is an independent business and the owners participate in governing the new entity $[11,14]$.

\subsection{The Motivations for Forming Joint Venture Partnerships}

Many reasons have been advanced for the extensive use of joint venture partnerships. One strong motivation for forming a joint venture is typically to reduce risk $[15,16]$, as the combination of resources and expertise of the two firms reduces the risk to both parties and the risks can be equally shared [17].

The joint sharing of costs [18] and the pooling of competencies and distinctive resources is a further strong motivation to form joint ventures $[16,18,19]$. Indeed, a common rationale for forming joint ventures is the aim of saving costs through the rationalization of fixed costs or by sharing with the joint venture partner capital investment programs [20]. This feature is especially important to this paper given the very high costs of acquiring and operating commercial freighter aircraft. Harrison [21] reports that investment capital can be easier to arrange as financial institutions evaluate the strength of two or more businesses instead of one. Kogut [22] (p. 132) also suggests that "a joint venture not only shares the investment burden, but sometimes reduces it, as the parties may bring different skills, thereby lowering the total investment cost".

Synergy is a further cited source of gains achieved from joint ventures [14]. A joint use of complementary resources, competencies, and skills possessed by the different firms can create synergistic effects [23]. Such benefits may not be possible if the firms are acting alone. A further motivation for forming joint ventures is the potential expansion of the joint venture partner customer base as the joint venture can enable a partner to expand the size of its customer base by utilizing its partner's strength in different geographic markets [20]. Joint ventures can also assist companies in accessing new markets [23,24]; increase their market-share [17]; enhancing their competitive position in markets; diversifying company operations; and participating in the industry's evolution [25]. A joint venture may also enable the partners to capture competitive advantage, as the joint venture may be able to pre-empt competitors, thereby allowing the joint venture firms to expand their customer base (as well as their market-share) [26].

\subsection{Joint Venture Success Factors}

Many key success factors have been suggested for joint ventures. First, the selection of the partner is critical. There must be the correct 'fit' for the specific joint venture. For this 'fit', the partners should have complementary technical skills and resources, compatible cultures, and clearly-defined objectives and performance criteria [20]. Second, there must be a spirit of trust, cooperation, and integrity. Third, both strategic and operational synergies must prevail between the partners. The expectations of the results of the joint venture should be reasonable [27]. Fourth, as the joint venture matures the parent firms must be willing to address new risks and be prepared to change the structure of the 
organisation in response to changing operating conditions [28]. A further, and very important factor, is a favourable past association with the other partner [29-31].

\subsection{Joint Ventures in the Global Air Cargo Industry}

Joint ventures (JVs) are increasingly becoming a popular strategy in the world airline industry. Joint ventures are being formed in both the passenger and air cargo segments of the industry [32]. These joint ventures are enabling airlines to deliver greater choice to consumers, whilst at the same airlines are growing businesses. Examples of passenger joint ventures include the Air France-KLM-Alitalia and Delta JV over the Atlantic; Japan Airlines-British Airways and Finnair JV linking Japan and Europe; and the All Nippon Airways (ANA)-United JV across the Pacific [32]. In the air cargo industry, examples of recent joint ventures include the All Nippon Airways (ANA) and Lufthansa Cargo AG innovative air cargo joint venture on Japan-Europe routes. This joint venture took effect on 1 December 2014. Under the JV agreement, both ANA and Lufthansa have commenced joint sales of shipments on flights from Japan to Europe [33]. In April 2017, United Airlines (UAL) and Lufthansa Cargo signed a joint venture agreement for extensive cargo cooperation on routes between the U.S. and Europe. The two partners plan to provide a wide range of benefits to customers by cooperating on the availability of their air cargo capacity and aligning cargo reservations and handling processes. The two carriers' joint venture route network will provide greater flexibility and will also offer time savings to customers with thousands of new route combinations and more than 600 direct connections per week between the U.S. and Europe. The combined United Airlines and Lufthansa route network offering creates additional benefits for customers through access from either partner's cargo booking channels together with coordinated handling processes and transfers at many airports served by the two airlines [34].

There are a range of factors that are leading to formation of joint ventures in the global air cargo (as well as the passenger) industry. International air transport operates within the framework of the 1944 Chicago Convention on International Civil Aviation and has been traditionally administered by a complex network of multilateral government air services agreements (ASA's) and International Air Transport Association (IATA) rules [35,36]. Commercial air rights are contained in bilateral air services agreements that are negotiated between individual countries $[37,38]$. However, in some instances bilateral agreements have significantly restricted the freedom of individual scheduled airlines and, as a result has constrained competition in the international air transport industry. Confronted with these restrictions, airlines have entered into joint ventures as these JVs provide the means for international airlines to obtain access to new markets, and to offer new services [39].

Following the privatization of airlines, especially in Europe and the deregulation of the United States airline market in 1978 [40], the desire for airlines to expand route networks internationally has resulted in increased competition between airlines. However, existing regulatory policies that restrict the takeover and use of foreign resources pose challenges to airlines. Although there are examples of firms acquiring equity stakes in international airlines, most governments do not permit complete foreign ownership of domestic airlines [41].

Joint ventures and alliance agreements also enable partner airlines to increase efficiency, reduce their costs by cutting back on fixed costs and eliminating redundant operations. Furthermore, by coordinating aircraft and flight schedules, the member airlines can reduce their fleet requirements or take greater advantage of the capacity that is offered, as operating a larger aircraft is more suitable for matching the aircraft size with the demand of a specific route. Other JV benefits include the shared use of ground handling arrangements and airport facilities and staff, joint procurement of fuel and amenities, and cooperative advertising and promotional campaigns [41].

\subsection{Past Failures of Air Cargo Alliances}

Strategic alliances, such as the oneworld, Star, and SkyTeam alliances have been in existence for airline passenger transport since the 1990s. Global airline alliances are bilateral or multilateral 
agreements in which the alliance member airlines share similar business objectives and they coordinate their services to attain their common aims [42]. Alliances are formed to create global service networks and to enable airlines to enter and establish an identity in new markets without providing aircraft and/or having full traffic rights, and to offer services that would be unprofitable if operated alone. Alliances create marketing advantages as consumers have demonstrated a preference for dealing with airlines with large route networks to minimize their own cost of travel, to obtain better services, and to take advantage of more attractive frequent flyer programs. Alliances can result in better access at congested airports and reduce costs through economies of scale. The major aim of an alliance is, therefore, to enhance member airlines' competitive positions, and to achieve higher profits for each of the members [37]. Oum et al. [43] have found that strategic alliances involving high-level cooperation tend to increase member airlines' productivity and profitability.

Strategic considerations and efficiency gains have also promoted the development of alliances within the global air cargo industry. These alliances primarily developed from existing passenger alliances, for example, SkyTeam Cargo Alliance from SkyTeam (AeroMexico Cargo, Air France-KLM Cargo, Alitalia Cargo, Czech Airlines Cargo, Delta Airlines Cargo, Korean Airlines Cargo) and the WOW Cargo Alliance from Star Alliance members (Lufthansa Cargo, Japan Airlines, SAS Cargo, Singapore Airlines) [44]. The WOW Cargo Alliance is now largely inactive [45,46].

However, air cargo alliances have often proved to be problematic. The reasons that strategic air cargo alliances have proved problematic are primarily driven by the air cargo market characteristics, that is, demand concentration, airline load factor considerations, uniform product appearance, coordination/cooperation arrangements between airlines, heterogeneity of goods and products shipped by air cargo, the time sensitivity of air cargo [44], the lack of economies of scale and scope [4], differences in member business processes and technology platforms, and cultural differences [47]. Further, air cargo is normally marketed more as a commodity rather than a brand. Airlines often have problems marketing their air cargo products as a brand and, therefore, an alliance brand may be even harder still [4].

Notwithstanding, some airlines have displayed great interest in working more collaboratively, and have developed strategic partnerships, with selected air freight forwarders [5,48,49]. Successful cooperation in the air cargo industry exists either as vertically integrated cooperation or as strategic partnerships between airlines and air freight forwarders. The objective of closer partnerships between airlines and freight forwarders is to offer optimized product offerings to end customers [44]. Additionally, as previously noted, the alliances that have emerged between airlines and air freight forwarders are partly intended to meet the competitive challenge posed by the integrators [6]. The global air express market is considered very profitable as shippers are more prepared to pay higher prices due to the time-sensitive nature of their goods being shipped. Thus, the combined services of air cargo-carrying airlines and air freight forwarders may potentially enable them to participate in this market segment [44].

\subsection{Porters Five Forces Model}

Prior to a firm defining its business level strategy, it must understand what forces influence profits in an industry [50]. One tool that is available for conducting this analysis is Porter's Five Forces Model [51]. Porter's Five Forces Model is based on industrial organization (IO) economics. This speciality within the economics discipline argues that firms competing in a particular industry confront forces within that industry that substantially affect profitability. If a firm has an understanding of these forces, then it can define a business-level strategy that enables the firm to either take advantage of, or protect itself from, these forces, which subsequently allows the firm to be consistently profitable. Porter's model focuses on the five forces in an industry (buyers, suppliers, new entrants, substitution, and rivalry) impact each other [50]. The model provides a framework for assessing and evaluating the strength and position of a firm [52]. Figure 1 summarizes the model. 


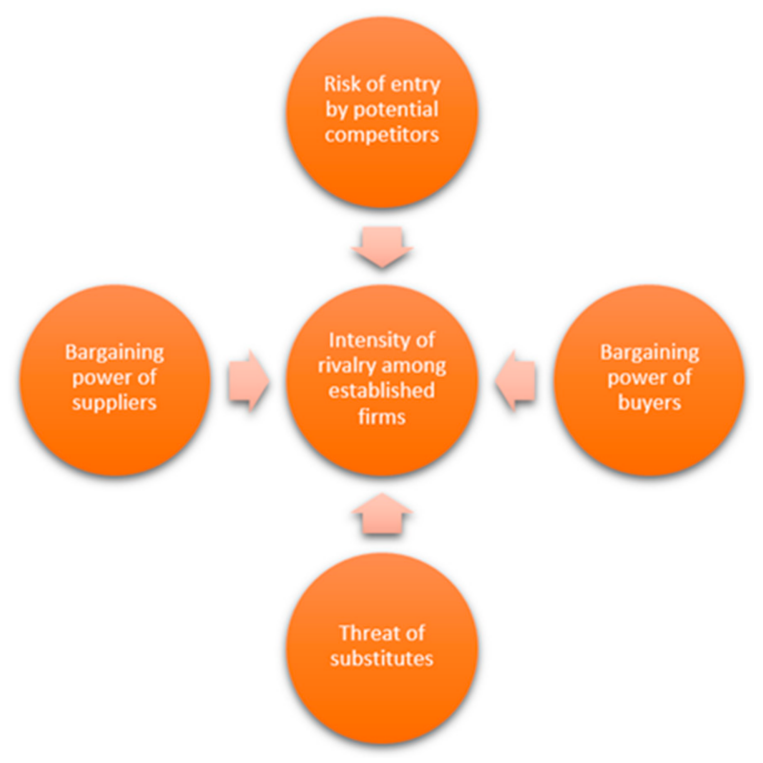

Figure 1. Porter's Five Forces model. Source: adapted from [53] (p. 378).

\subsubsection{Threat of New Market Entrants}

If an industry is experiencing high returns, then other firms will wish to enter the industry [50]. New firms entering an industry bring new capacity, the desire to achieve market share, and often substantial resources. Firms that are diversifying through acquisition into the industry from their participation in other markets often leverage their resources to cause a market shake-up. The seriousness of the new entrant depends upon the present barriers to market entry and on the reaction from the incumbents that the new entrant can anticipate [54] (p.13). There are six principal sources of barriers to market entry:

1. Economies of scale: these economies deter entry by forcing the new entrant to enter the market on a large scale or to accept a cost disadvantage.

2. Product differentiation: brand identification creates a market entry barrier by forcing new entrants to invest heavily to overcome customer loyalty. Advertising, customer service, being first in the industry and differences in products and services are among the factors fostering brand identification.

3. Capital requirements: the requirement to invest large financial resources to compete in the market creates a barrier to market entry, especially if the capital is required for unrecoverable expenditures on advertising or research and development.

4. Cost disadvantages independent of firm size: entrenched incumbents may enjoy cost advantages that are not available to potential competitors, no matter what their size and attainable economies of scale.

5. Access to distribution channels: the new market entrant must secure distribution of their product or service. In some cases this barrier is so high that, to surmount it, a new entrant must create its own distribution channels.

6. Government policy: the government can restrict, or even foreclose, entry to industries through controls, such as, license requirements, controls on air and water pollution, and safety regulations [54] (pp. 13-15).

\subsubsection{Bargaining Power of Suppliers}

According to Ahlstrom and Bruton [50] (p. 133), 'suppliers are those firms or individuals that provide input into the creation of the industry's output'. Suppliers can exert bargaining power on 
incumbents in an industry by through price rises or reducing the quality of purchased goods and services. Powerful suppliers are, therefore, able to squeeze profitability from an industry that is unable to recoup cost increases in their own prices. Customers can force prices down, demand higher quality or greater service, and play rivals against each other, which is all at the expense of industry profits. A supplier group is powerful if:

- It is dominated by a few firms and is more concentrated than the industry it sells to.

- Its product is unique or at least differentiated, or if switching costs have been built up. Switching costs are fixed costs that buyers confront in changing suppliers.

- It is not obliged to contend with other products for sale to the industry.

- It poses a credible threat of integrating forward into the industry's business.

- The industry is not an important customer of the supplier group [54] (pp. 16-17).

\subsubsection{Bargaining Power of Buyers}

Buyers are individuals or firms that purchases the output of an industry. This group can include consumers, distributors and industrial buyers [50]. A buyer group is considered powerful if:

- It is concentrated or purchases in large volumes. Large-volume buyers are especially powerful forces if heavy fixed costs characterise the industry.

- The products that the buyer group acquires from the standard or undifferentiated.

- The products or services that the group purchases from the industry form a component of its product and represents a significant fraction of its cost. The buyers are most likely to look for favourable prices and purchase selectively.

- It earns low profits, which creates the incentive to lower its purchasing cost.

- The industry's product is considered unimportant to the quality of the buyers' product or services

- The industry's product does not save the buyer money.

- The buyers pose a credible threat of integrating backward to produce the industry's product [54] (p. 17).

\subsubsection{Threat of Substitutes}

Substitute products are the products of different firms or industries that are able to satisfy similar customer requirements [55] (p. 63). Through placing a ceiling on the prices that it can charge, substitute products or services restrict the potential of an industry. Unless the industry can upgrade the quality of its products or services or differentiate them somehow, the industry will suffer in earnings, and possibly even in market growth [54] (p. 19).

\subsubsection{Intensity of Rivalry among Established Firms}

Rivalry between incumbent firms takes the familiar form of jockeying for position. Incumbents use tactics such as price competition, product introduction, and advertsing campaigns. Intense rivalry to the precense of a number of factors:

- There are numerous competitors or competitors are of approximately the same size and power.

- Industry growth is slow. This precipitates competition for market share amongst expansionminded members.

- The product or service lacks differentiation or switching costs, which secure buyers and protect one incumbent from attacks its customer from another rival.

- There are high fixed costs and the product is perishable, creating a strong temptation to reduce prices.

- Capacity is typically introduced in large increments.

- Exit barriers are high. High exit barriers can keep firms competing even though they may be earning low or possibly even negative returns on their investment [54] (pp. 20-21). 


\section{Research Method}

\subsection{Research Approach}

The research undertaken in this study was broadly exploratory in nature $[56,57]$ and follows an inductive approach using a qualitative longitudinal case study approach. The goal of such an approach is to expand and build theories rather than perform statistical analysis or to test a certain hypothesis [58]. As Yin [59] notes, a case study, whilst like an experiment, does not represent a sample, and the researcher's role is to expand and generalize theories (analytical generalization) and not to enumerate frequencies (statistical generalization). A case study allows for the exploration of complex phenomena [59,60] and enables the collection of rich, explanatory information [61]. A further benefit of case studies is that they also permit researchers to build theory and connect with practice [62].

\subsection{Data Collection}

The qualitative data for this study was obtained from a range of documents, including the AeroLogic, DHL Express and Lufthansa Cargo AG websites, DHL Express and Lufthansa Cargo AG press releases and annual reports, journal and air transport industry-related magazines, industry reports, and press articles. An exhaustive source of the air transport and cargo industry-related magazines-Air Transport World, Airline Business, Flight International, Journal of Commerce, and Payload Asia - was also conducted. These industry publications were accessed in the Proquest ABI/INFORM and EBSCO Information Sources databases. Table 1 shows the publications used in the study and the time period for which the key word search was conducted. A search of the SCOPUS and Google Scholar databases was also undertaken. The keywords used in the database searches were 'AeroLogic', 'air cargo industry joint ventures', 'joint ventures', 'Lufthansa Cargo and DHL Express joint venture'.

Table 1. Publication, time-period, and database source used in the study.

\begin{tabular}{ccc}
\hline Publication & Time Period & Database \\
\hline Air Cargo World & $2001-2017$ & EBSCO Host \\
Air Transport World & $1991-2017$ & Proquest ABI/INFORM \\
Airline Business & $2002-2017$ & Proquest ABI/INFORM \\
Flight International & $2004-2017$ & Proquest ABI/INFORM \\
Journal of Commerce & $1996-2017$ & Proquest ABI/INFORM \\
\hline
\end{tabular}

The study, therefore, used secondary data analysis to investigate the research problem. The three principles of data collection suggested by Yin [57] were followed in this study: the use of multiple sources of case evidence, creation of a database on the subject, and the establishment of a chain of evidence.

\subsection{Document Analysis Process}

The empirical data collected for the case studies was examined using document analysis. Document analysis is often used in case studies and focuses on the information and data from formal documents and company records $[63,64]$. The documents collected for the study were examined according to four criteria: authenticity, credibility, representativeness, and meaning $[65,66]$.

Prior to conducting the formal analysis of the documents gathered in the study, the context in which the documents were created was determined and the authenticity of the documents was assessed. Authenticity involves an assessment of the collected documents for their soundness and authorship. Scott and Marshall [67] (p. 188) note that 'soundness refers to whether the document is complete and whether it is an original and sound copy. Authorship relates to such issues as collective or institutional authorship. As previously noted, in this study the source of the case study documents was from the AeroLogic, Lufthansa Cargo AG websites, DHL and Lufthansa annual reports and press releases, and case study-related articles from the leading air transport and air cargo industry-related 
publications. These publications included Air Cargo World, Air Transport World, Airline Business, Flight International, Journal of Commerce, and Payload Asia. The documents were available in the public domain.

Authenticity also addresses whether their production is original, are not of questionable origin, and that they have not been subsequently altered. If a document has been found to be transformed, through textual editing, marginalia, or any other means, then the researcher is required to clearly identify those alterations. Once it has been determined by the researcher that the document is "genuine and of unquestionable origin," then the material can be considered "valid" as an artefact [68]. The documents gathered for the present study were all found to be genuine and there was no evidence of any changes being made to documents that were collected.

Whilst any form of qualitative data may be original and genuine, that is, authentic, it is possible that the content may still be distorted in some manner. Thus, a second criterion in appraising materials is determining their credibility and identifying whether the document's information is both honest and accurate [68]. Hence, credibility refers to the extent to which a document is sincere and not distorted and is free from error and evasion. In assessing this criterion, it is necessary for the researcher to determine whether the document can be regarded as a credible, worthwhile piece of evidence and, also in some instances, whether it is accurate [69]. The documents gathered for the present study were all found to be free of error. The accuracy of all the documents were checked to ensure that they were credible pieces of evidence.

A third criterion, representativeness, refers to the "general problem of assessing the typicality or otherwise of the evidence" [69] (p. 7) collected for the study. A document's representativeness may become distorted over time. This is because with the passing of time the survival rate of certain materials becomes greater as the items may have been viewed as less valuable. Accordingly, the document(s) may have been stored away, rarely viewed following their point of origination and, hence, preserved. Furthermore, some important documents do not survive because their great significance caused them to become well used and worn. Consequently, they may be discarded while, on the other hand, less important documents survive because they attract so little use [68]. In this study, the Lufthansa and DHL Express press releases and annual reports were available in the public domain. The news-items on AeroLogic were stored in the Proquest ABI/INFORM or EBSCOhost databases, thus, the documents had been preserved. Thus, the issue of a document being well used and worn did not arise.

A final criterion-meaning-refers to the degree to which the evidence is clear and comprehensible to the researcher(s) $[69,70]$ and concerns the assessment of the actual documents gathered for the study [70]. Kridel [68] notes that "coupled with this semiotic and intertextual examination is whether the document's content is appropriately situated within its historical context; this is ascertained, in part, by the method in which meaning is constructed and perceived by its originally intended audience".

The qualitative document analysis process in the present study was undertaken in six phases as shown in Table 2.

Table 2. The study's document analysis process.

\begin{tabular}{cl}
\hline Phase of the Study & \multicolumn{1}{c}{ Activity/Task Undertaken } \\
\hline Phase 1 & $\begin{array}{l}\text { This phase involved planning the types and required documentation and their availability. } \\
\text { The data collection involved gathering the documents and developing and implementing } \\
\text { a scheme for the document management; }\end{array}$ \\
Phase 2 & $\begin{array}{l}\text { Documents were reviewed to assess their authenticity, credibility and to identify any } \\
\text { potential bias } \\
\text { The content of the collected documents was interrogated, and the key themes and issues } \\
\text { were identified } \\
\text { This phase involved the reflection and refinement to identify any difficulties associated } \\
\text { with the documents, reviewing sources, as well as exploring the documents content } \\
\text { The analysis of the data was completed in this final phase of the study }\end{array}$ \\
Phase 5 &
\end{tabular}


The documents gathered for the study covered the period 1991 to 2017, that is, the documents covered the period from the inception of the AeroLogic JV between DHL Express and Lufthansa Cargo through to the present time of the study.

All pertinent documents were downloaded into a case study database [57]. The documents gathered for the study were all in English. Each document was carefully read and key themes, such as aircraft fleet, airline route network, product, and strategic benefits, were coded and recorded. This study followed the recommendation of van Schoor [72] (p. 94), to "avoid bias, documents from different sources were analyzed". Triangulation is viewed as a means to add discipline to a study in both qualitative and quantitative research. One of the principal reasons for triangulation is the recognition that bias can be introduced if only one way of obtaining and interpreting data is used in the study. Triangulation is used in qualitative research as a procedure to seek stronger accuracy, employ cross-referencing, or demonstrate the verification of the data. This study used data triangulation with the documents being collected from various sources. This approach helped verify the themes that were detected in the documents gathered in the study [73]. The data collection was also guided by the case study protocol [59].

\section{Case Study Results}

\subsection{The Global Air Cargo and Express Industry: A Background Note}

Before proceeding to the case study, a review of the recent growth and trends in the global air cargo and express industry is useful as it sets the context underpinning the strategic direction of the DHL Express and Lufthansa Cargo 'AeroLogic' joint venture.

The global air cargo industry has grown rapidly in recent decades and is now an integral part of the global economy, carrying around 35\% of world export trade (by value) [74]. Figure 2 shows the growth in total annual world domestic/international freight enplaned air cargo tonnage and freight tonne kilometres performed (FTKs) from 1990 to 2016. Over this period, the total annual enplaned tonnage and FTKs grew from 18.4 million tons and 58.9 billion FTKs in 1990 to an estimated 52.6 million tons and 204.8 billion FTKs in 2016, respectively, as illustrated in Figure 2. This relationship is demonstrated in Figure 2 which shows that total world air cargo traffic (domestic and international FTKs) showed marked declines in 2001 and 2008 following the tragic events of September 11 and the 2008-2009 global financial crisis (GFC). A recession in the United States combined with the 9/11 terrorist attacks resulted in an unprecedented decline in global air cargo traffic [75,76]. The global recession saw global air cargo traffic fall by around 5\% in 2008 [77]. The global financial crisis (GFC) also adversely impacted world air cargo traffic volumes in 2009 (Figure 2) [78].

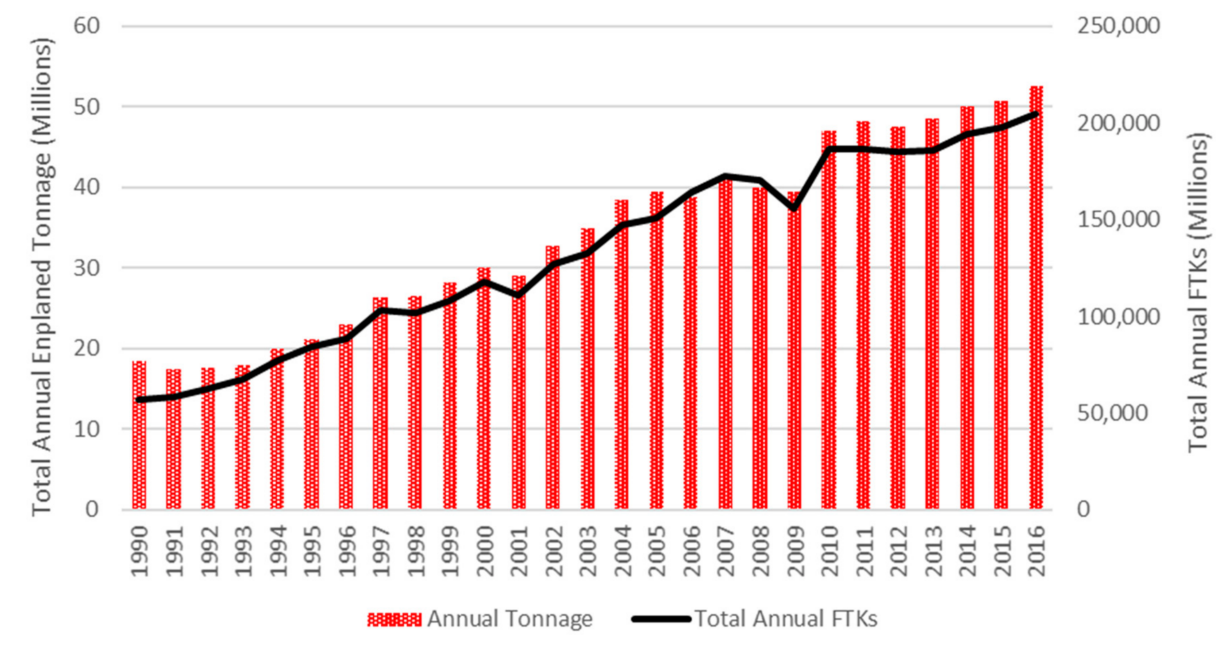

Figure 2. The development of global air cargo (domestic/international) enplaned tonnage and freight tonne kilometres performed (FTKs): 1990-2016. Note: 2016 preliminary data. Source: Data derived from [79]. 
The growth in world air cargo traffic has been driven by growing world trade volumes, technological progress, a decline in world air cargo yields, and changing manufacturing processes, such as make-to-order [80]. The liberalization of air cargo services in many markets has also enabled the expansion of air cargo services. Furthermore, the globalization of economic activity and the concomitant disaggregation of production networks have raised the importance of air cargo services not only to individual companies, but also to regions and nations [81]. Increased requirements on the supply chain, such as the reduction in times to ship products to markets, shortening of product life cycles, and the trend to source globally, have accentuated the requirement for fast and reliable transportation services [82]. Indeed, shippers have increasingly regarded the speed of the air cargo mode as compared to surface transport modes, as being ideally suited to their requirements for faster, more reliable delivery given the growing supply chain complexity [83]. Additionally, more firms around the world are increasingly recognizing that the higher costs of shipping goods by air cargo can be offset by reductions in inventory holding costs, warehousing, and packaging [84]. The rapid growth of e-commerce, and the growing importance of global companies' supply chain strategies have continually influenced the growth of the air cargo market in recent years [85,86].

However, the largest change in the world air cargo industry over the past three decades or so has been the growth in the express parcels sector [87], spearheaded by FedEx and United Parcel Service (UPS) in the United States. The major firms in this sector are FedEx, United Parcel Service (UPS), and DHL Express. In 2016, FedEx and UPS were ranked first and third, globally, in terms of total international and domestic FTKs performed [88]. The business models of firms like FedEx, DHL, and United Parcel Service (UPS), who operate on an integrated 'door-to-door' basis, suggests an important level of control over all chain operations and the ability to achieve high levels of efficiency. Not surprisingly these firms have captured significant market share in the express air freight markets [89] and, in more recent times, general cargo, and the integrators have branched out into the transportation of industrial shipments [90]. Furthermore, the integrators' business model not only focuses on the provision of a fully-integrated door-to-door product offering, but also on the provision of supply chain and logistics solutions, which are underpinned by highly-advanced IT systems.

\subsection{A Brief Background of the AeroLogic Joint Venture Partners}

\subsubsection{DHL Express}

DHL, an international air express company, was established in San Francisco in 1969. The company developed a niche market in the ocean freight sector by flying ahead with the shipment-related documentation. Arriving prior to the vessel, they were able to complete the discharge paperwork and expedite the turn-around of the cargoes by two to three days, thereby offering clients significant savings [91]. From this base, the three founders (Adrian Dalsay, Larry Hillblom, and Robert Lynn) established a lean operation focusing on time-critical, high-value goods-particularly documents [92]. The overnight express product was expanded to the banking sector, and then more broadly to the general business sector. In 1971, DHL commenced operations in the Pacific Basin, introducing services to the Philippines, followed by Japan, Hong Kong, Singapore, and Australia in 1972 [93].

Over the following decade, the company expanded its operations to Europe in 1974, Latin America in 1977, the Middle East in 1978 [94], and the Eastern Bloc countries in 1983. In 1983, DHL also opened its first hub at Cincinnati International Airport. An international hub was established in Brussels in 1985 [95]. DHL commenced operations in China in 1980 under an agency agreement with Sinotrans, the Chinese state transportation authority. Under the terms of the agreement, DHL provided services to and from China, and Sinotrans provided the in-country distribution services. In 1986, DHL formed a full joint venture partnership with Sinotrans, becoming the first integrator to establish its own offices and employees in China [92]. In 1990, DHL introduced services to Cuba and Mongolia [94]. DHL commenced air-express services to Vietnam in 1994, becoming the first express company to operate services to that country [93]. DHL also launched its Middle East regional distribution centre in Bahrain 
in 1994. This facility enabled DHL to process shipments faster and facilitated earlier deliveries to customers located in 16 countries in the Middle East [95].

An important milestone for the company occurred in 1990 when, to raise capital for future expansion, DHL, previously a private company, entered into an agreement with Lufthansa, Japan Airlines, and Nissho Iwai Trading Company, a Japanese trading firm, under which the three new partners purchased $12.5 \%$ of DHL's stock. Lufthansa and Japan Airlines each acquired $5 \%$ and Nissho Iwai $2.5 \%$. The agreement provided options for both Lufthansa and Japan Airlines to increase their shareholdings up to $25 \%$, respectively, and for Nissho Iwai to increase its shareholding to $7.5 \%$ over a period of 18 months, for a total of 57.5\% [94,96]. Lufthansa and Japan Airlines subsequently exercised their options in 1992, and together with Nissho Iwai, took control of 57\% of DHL International [97]. In 1998, Deutsche Post acquired a 22.5\% shareholding in DHL. By the end of 2002, Deutsche Post World Net completed its full takeover of DHL [98]. The company serves over 220 countries throughout the world [99]. In 2016, DHL Express revenues were $€ 14.03$ billion [100].

\subsubsection{Lufthansa Cargo AG}

Lufthansa Cargo AG, one of the world's major air cargo-carrying airlines, is regarded as a market leader in the global air cargo industry [101,102]. In 1926, the newly-formed German airline Deutsche Luft Hansa transported its first air cargo consignment, making it one of the world's earliest air cargo carriers. On 1 January 1995, Lufthansa Cargo Airlines, the airline's air cargo operation, was established as a totally autonomous public limited company, Lufthansa Cargo A.G. [103], with the strategic objective, according to Lufthansa, "to further reduce the substitutability of its product and to create a clearly identified Lufthansa Cargo product" [104]. Lufthansa Cargo now serves over 300 destinations in 100 countries using a combination of 12 dedicated Boeing MD11 freighter aircraft, five Boeing B777-200LRF freighter aircraft, and the lower-deck belly hold capacities on Lufthansa and Austrian Airlines Eurowings passenger aircraft, as well as an extensive road feeder service (RFS) network $[105,106]$. The bulk of the airline's cargo business is routed through its hub at Frankfurt Airport. Other hubs include Munich, and Vienna Airports [107]. Following Lufthansa's acquisition of Austrian Airlines, Lufthansa Cargo and Austrian Airlines created a joint subsidiary in 2010 to market the whole air cargo capacity of both airlines in Austria and the expansion of Vienna Airport into a hub for Lufthansa Cargo [108].

Lufthansa Cargo has operational equity stakes in:

- $\quad$ handling counts $\mathrm{GmbH}(100 \%)$

- Jettainer $\mathrm{GmbH}(100 \%)$

- time:matters $\mathrm{GmbH}(100 \%)$

- $\quad$ AeroLogic $\mathrm{GmbH}(50 \%)$

- Lufthansa Cargo Servicios Logísticos de Mexico, S.A. DE C.V. (100\%)

- Shenzhen Airport Int'l Cargo Terminal (ICCS) (50\%)

- Airmail Center Frankfurt GmbH (40\%)

- Shanghai, China-based Shanghai Pudong International Airport Cargo Terminal Co. Ltd. (PACTL) (29\%) [106]

In 2016, the airline transported around 1.6 million tonnes of freight and mail and sold 8.4 billion freight tonne-kilometres (FTKs) [106]. Lufthansa Cargo total revenues in 2016 were $€ 2.1$ billion [109].

\subsection{The Origin and Evolution of the AeroLogic Joint Venture}

As noted earlier, the roots of Lufthansa Cargo and DHL's relationship date back to the 1990s, when Lufthansa held a $25 \%$ shareholding in DHL, although mostly as a passive investor [49]. In April 2000, Lufthansa Cargo and Deutsche Post pooled their joint 50\% shareholdings in DHL into a new joint venture, AeroLogic $\mathrm{GmbH}$, to manage the voting rights of the two companies in DHL [110]. Lufthansa subsequently sold its DHL shareholding in 2001, but in 2002, following the 
phase-out of its quick-change $(\mathrm{QC})$ aircraft fleet-which were used to provide night-time air cargo services into Cologne-it replaced that capacity through cooperation with DHL on its intra-European network of Boeing B757 freighters [40,98].

In February 2004, Lufthansa Cargo and DHL concluded a strategic partnership agreement whereby Lufthansa was to deploy capacity equivalent to seven Boeing MD11 freighters on five intercontinental routes for DHL $[49,111]$. The capacity on the freighter services was divided on a 50/50 basis. Under the "Aerologic Intercontinental" joint venture, Lufthansa operated dedicated freighter services from three European DHL hubs—Brussels, Cologne, and Birmingham-to key Asian and North American destinations [112]. The strategic alliance agreement with DHL assisted Lufthansa by ensuring long-term capacity utilization and less seasonal traffic variations, a contributory factor to declining profits being experienced at the time of the conclusion of the joint venture agreement with DHL [113] (p. 47). In addition, the agreement with DHL permitted Lufthansa to phase out its older Boeing B747-200 freighter fleet and refocus operations around its Boeing MD11 freighter fleet [91]. Originally based in Cologne, these services were transferred in October 2007 to Leipzig/Halle Airport, the DHL Express European express network primary hub [9]. The agreement between the two partners was to run through to 2009. However, both organizations foresaw the pact extending well past that timeframe by using AeroLogic as a vehicle for achieving synergies offered by their respective activities [113].

In July 2007, plans were made public by DHL and Lufthansa Cargo that they intended to establish a joint company for express and air cargo transport alike. The initial acronym of the project was NewCo (New Company) but this was later was replaced by its present brand 'AeroLogic' [114]. In January 2008, following eight years of growing cooperation between the two companies, Lufthansa Cargo and DHL Express announced their proposed joint venture air cargo airline: AeroLogic. The joint venture airline is between Deutsche Lufthansa AG and Deutsche Post Beteiligungen Holding AG who have entrusted Lufthansa Cargo and DHL Express with operational responsibility [115]. AeroLogic was established as a completely new airline with $€ 50$ million in start-up capital [45] and has its own Air Operator's Certificate (AOC), air traffic rights, and is responsible for all its flight operations, including aircraft, flight crews, and route network [115].

The new company officially started business on 28 January 2008 with an initial staff of 20 employees [116]. The company now has a staff of around 310, 220 of which are flight deck crew [115].

On 19 June 2009, AeroLogic officially commenced commercial operations. With the delivery of its first Boeing 777-200LRF aircraft and after securing the Air Operator's Certificate (AOC) from the German Aviation Authority (LBA), the company was ready to commence commercial operations. The company's maiden flight was on 29 June 2009, flying first from Leipzig to Bahrain and then onto Hong Kong before returning to Leipzig Airport via the same intermediate points. The first AeroLogic flight operated under the auspices of Lufthansa Cargo took place on 4 July 2009, on the route Leipzig/Halle-Bahrain-Singapore-Delhi and back to Leipzig [114].

Today, AeroLogic operates a fleet of ten Boeing B777-200LRF freighter aircraft over route network compromising 20 destinations in Europe, Asia, the Middle East, and North America [115]. The following sections examine the development of the AeroLogic joint venture and its progress to date.

\subsection{The Core Elements of AeroLogic's Business Model}

According to Whyte and Lohmann [117] (p. 108), a business model 'is the conceptual structure or plan that defines how a company conducts its business'. The core elements of a dedicated freighter airline include its product, route network, aircraft fleet, airports, distribution system, and staff. Another critical element of the business model is the airline's strategy [118].

\subsubsection{AeroLogic's Freighter Aircraft Type and Fleet Requirements}

In the global air cargo industry, there are certain drivers of each airline's dedicated freighter fleet strategy. Global shipping trends, noise and emission standards, aircraft reliability, and how the 
fleet fits into the airline's business model are of fundamental importance. Importantly, airlines plan their aircraft fleet in terms of years and even decades ahead. Key selection requirements include the evaluated aircraft's mission, flexibility of new or used aircraft, fleet commonality, engine and parts availability, and whether the aircraft satisfies all regulatory requirements [119]. Other key factors considered include the aircraft design density, access door dimensions, fuselage cross-section and aircraft weights $[120,121]$, payload/range performance, and freighter operating costs, including fuel and capital costs [122].

After an intense review of its requirements-which included aircraft capacity, fuel consumption, environmental friendliness, market availability, and aircraft range-AeroLogic selected the Boeing 777-200LRF aircraft [123]. Aimed at the large freighter market and launched in May 2005 on the back of the newly-available Boeing 777-200LR airframe/engine combination [124], the Boeing 777-200LRF aircraft has a revenue payload capability of 112 tons (102 metric tons) [125]. The economics of the aircraft are extremely favourable with cargo density identical to the Boeing B747-400F, and $18 \%$ lower fuel burn than the Boeing B747-400F. The Boeing B777-200LRF freighter aircraft can carry its full cargo load over a range of 9070 kilometres [126], which enables non-stop flights from AeroLogic's home base at Leipzig/Halle Airport, Germany, to key Asian growth markets, thereby reducing the elapsed time of shipments [127]. AeroLogic $[115,128]$ also states that due to its ultramodern technology, the aircraft is not only reliable and cost-efficient, but also low-maintenance and low-emission.

AeroLogic originally placed an order for 11 Boeing B777-200LRF aircraft that were due to be delivered by the end of $2012[94,104]$. However, the company scaled back its fleet plans due to declining world air cargo volumes and decided to deploy a fleet of eight Boeing B777-200LRFs instead [129]. The first of AeroLogic's eight brand-new Boeing 777-200LRF freighters arrived at Leipzig/Halle Airport on 13 May 2009. The aircraft was the first Boeing 777-200LRF freighter aircraft registered in Germany. AeroLogic's second aircraft was delivered in July 2009, with the third and fourth aircraft delivered in December 2009. The remaining four aircraft were delivered to Aerologic in 2010 [130].

Following the delivery of its first aircraft, AeroLogic was required to complete a certification process and acquire its operating license from Germany's Federal Office for Civil Aviation. This was followed by tests and training courses in the areas of maintenance and ground operations, as well as flight operations, prior to the planned launch of AeroLogic's scheduled services on 29 June 2009. At the time of the present study, AeroLogic had a fleet of ten Boeing B777-200LRF aircraft.

The key specification of AeroLogic's Boeing B777-200LRF aircraft are presented in Table 3.

Table 3. Key specifications of the AeroLogic Boeing B777-200LRF aircraft.

\begin{tabular}{cc}
\hline Wingspan & $64.8 \mathrm{~m}$ \\
Length & $63.7 \mathrm{~m}$ \\
Maximum Payload & 106 tons \\
Maximum Landing Weight & 261 tons \\
Maximum Take-Off Weight & 347 tons \\
Engines & GE90-110B1L \\
Main Deck ULD Configuration ${ }^{1}$ & 27 AMX Containers \\
Lower Deck ULD Configuration & 32 LD3 Containers \\
\hline
\end{tabular}

Note. ${ }^{1}$. Aircraft unit load devices (ULDs) are pallets and containers which are used to carry air cargo, mail and passengers' baggage on wide-body passenger and dedicated freighter aircraft [131]. Source: [125].

An airline can purchase aircraft outright or acquire them through rental (leasing) agreements [46,132]. The AeroLogic joint venture partners will lease, rather than purchase, their fleet of eight Boeing B777-200LRF freighter aircraft $[133,134]$. On 28 January 2008, Boeing Commercial Airplanes announced that Deucallion Capital VII, a company advised and managed by DVB Bank AG, had purchased eight Boeing B777-200LRF freighter aircraft for lease to AeroLogic. The aircraft order was valued at around \$USD 2 billion at list prices [135]. DVB lent \$USD 600 million for the aircraft pre-delivery payments. The aircraft have been 
subsequently sold by Deucallion Capital VII to the KG Fund, Deutsche Capital Management, who will lease the aircraft to AeroLogic for a period of 10 years [136].

AeroLogic has followed a similar aircraft fleet strategy to both the combination airlines operating freighter aircraft and the dedicated all-cargo airlines, such as Cargolux and Nippon Cargo Airline (NCA) in that it operates a homogeneous freighter fleet. Some cargo airlines purchase their aircraft direct from the manufacturers (Airbus or Boeing Commercial Airplanes), lease them from a leasing company, or acquire passenger-to-freighter converted aircraft. As noted, AeroLogic decided to operate new Boeing B777-200LRF aircraft on a leased basis.

\subsubsection{Location of the AeroLogic Operational Base}

In the global air cargo industry both the combination airlines and dedicated all-cargo airlines, as well as the integrators, operate from their home airport hub; for example, Cargolux Airline's primary hub is located at Luxembourg Findel Airport, Cathay Pacific Airways' primary hub is at Hong Kong International Airport, and Etihad Airways' principal hub is Abu Dhabi International Airport. AeroLogic has followed a similar strategy to these other carriers.

Eastern Germany's Leipzig/Halle Airport was selected as AeroLogic's operational base [137]. In 2004, DHL decided to move its European intercontinental hub to Leipzig-Halle Airport, replacing its previous hub located at Brussels Zaventem Airport [138]. Deutsche Post invested around $€ 300$ million in constructing a new distribution hub for its DHL Express division at the Leipzig/Halle airport [139]. This includes an aircraft hangar, apron area, fuelling station and administrative offices. The Leipzig hub is strategically located to provide north-south and east-west services to Europe, and also connects both the established and emerging markets in Central and Eastern Europe and Asia [140]. In addition to Leipzig's close proximity to major markets in the emerging countries, the Leipzig/Halle Airport provided DHL with a location that could be easily expanded in the future [139]. Furthermore, the proximity to the airport is also valued by some of the world's largest Internet retailers. For example, Amazon.com maintains a logistics centre in Leipzig [141].

Leipzig/Halle Airport is congestion-free, has two $3.6 \mathrm{~km}$ long runways and offers significant untapped aircraft landing and take-off slots. Since 2000, the airport's owner, Mitteldeutsche Airport Holding, has spent around $€ 1.5$ billion upgrading the airport [142]. The completion of the second runway has provided the airport with a vital parallel runway system [134]. The airport's decision to construct a second runway had been planned prior to the DHL decision to move their European hub from Brussels. The construction of the second runway was a critical pre-requisite for DHL [142]. Furthermore, Leipzig/Halle Airport has a 24-hour operating licence for freighter aircraft [143].

Leipzig/Halle Airport has also completed construction on what is known as 'Cargo Area South'. The ramp apron area (12 hectares) can accommodate up to six freighter aircraft. The World-Cargo-Center GmbH (WCC) operates a 20,000 square metre air cargo terminal, capable of handling 200,000 tonnes annually. The WCC also has direct access to the airport apron. To allow the transhipment between aircraft and trucks the freight centre is equipped with 38 loading gates which trucks can easily dock on to. A total of 171 parking spaces are available to the tenants on the grounds. In addition, $3400 \mathrm{~m}^{2}$ office space is available with a direct connection to the cargo building [144]. In preparation for the planned launch of the AeroLogic operations, Lufthansa Cargo moved operations into the Leipzig Airport's World Cargo Centre (which opened in 2007) [145]. The key air cargo and freighter aircraft handling infrastructure are as follows:

- Sufficient airside apron parking space to accommodate aircraft up to International Civil Aviation Organization (ICAO) Category F (Apron 2, Apron 3). Note: Apron 2 can accommodate up to six Category F aircraft;

- World Cargo Centre (20,000 square metres) with direct access to Apron 2 (located in the airport security area);

- Close proximity to motorway and main roads;

- Railway ramp and track; 
- Veterinary/Plant Border Inspection Post; and

- Animal Export Centre [146].

\subsubsection{AeroLogic's Route Network}

An airline's network design is the most important attribute of its product offering [147] as it is the primary driver for generating an airline's revenues and costs. Network design is also a source of competitive strength or weakness for an airline [148] (p. 29). A further principal benefit for an all-cargo airline is its ability to offer customers flight schedules attuned to the requirements of customers [149]. AeroLogic's network and operations are planned around both the JV partner's discrete requirements with the available air cargo capacity being used by the two partners. The airline operates express services for DHL during weekdays, and switches to the carriage of general air cargo flights for Lufthansa Cargo at weekends. The two partners are responsible for all salesand warehousing-related activities and continue to market and sell their air cargo capacities on the AeroLogic services separately [123].

During the 2009/2010 summer schedule AeroLogic served the DHL Express destinations of Bahrain, Delhi, East Midlands, Sharjah, and Singapore. Whilst Lufthansa Cargo supplemented their own capacity by deploying the AeroLogic Boeing B777-200LRF freighter aircraft on a Leipzig-TashkentHong Kong-Tashkent-Leipzig routing and from Frankfurt to Atlanta and Chicago services on weekends (Figure 3).

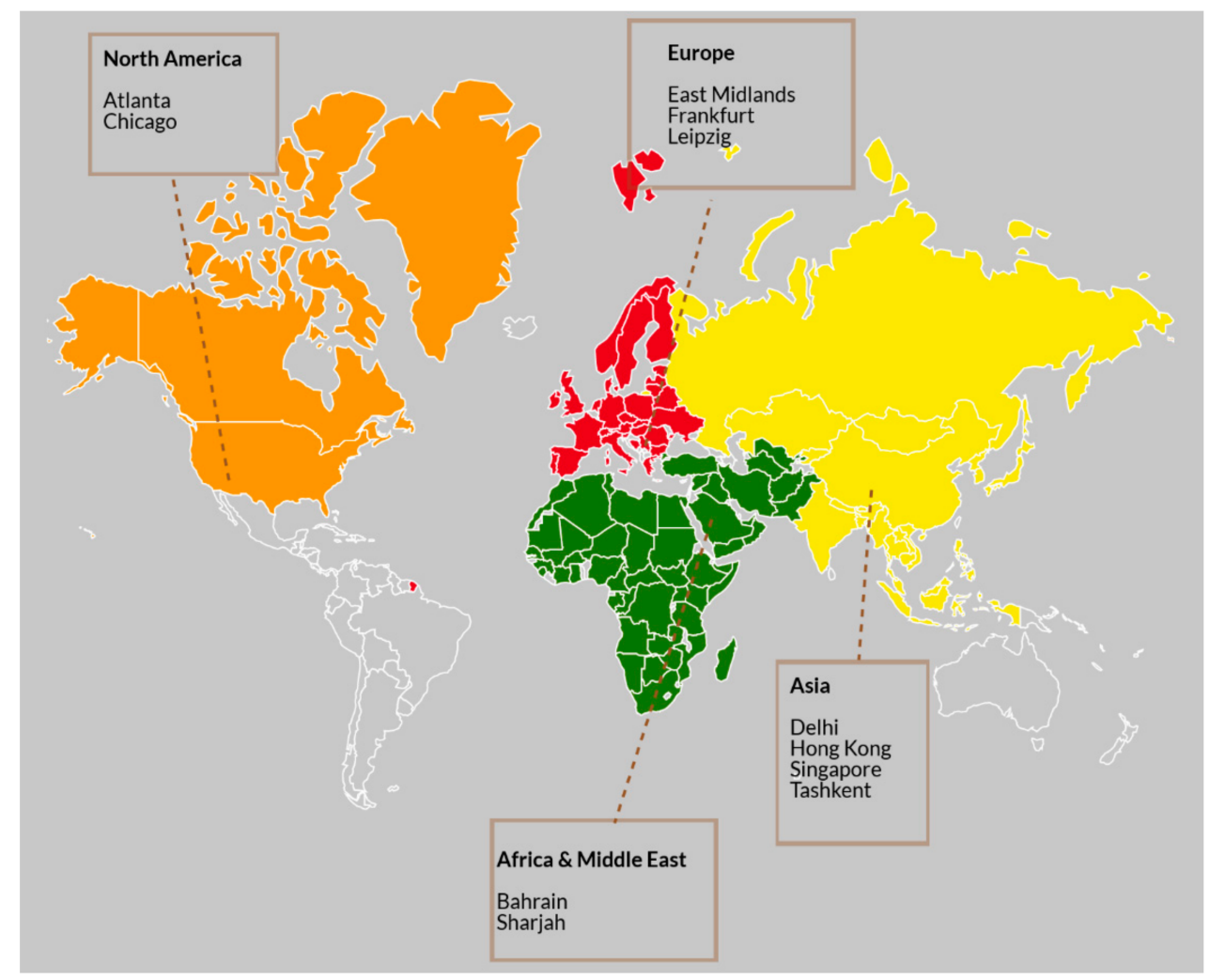

Figure 3. The AeroLogic route network: Winter 2009/2010 schedule. Legend: ATL-Atlanta; BAH-Bahrain; DEL-Delhi; EMA-East Midlands; FRA-Frankfurt; HKG-Hong Kong; LEJ-Leipzig/Halle Airport; ORD-Chicago; SHJ-Sharjah; SIN-Singapore; TAS-Tashkent. Source: [150].

On 30 July 2009, AeroLogic increased its Leipzig-Bahrain-Singapore-New Delhi Leipzig services from four to ten weekly services [151]. Following the delivery of two additional Boeing B777-200LRF freighter aircraft in December 2009, the company announced a further expansion of its services 
effective the 14 January 2010, with the introduction of new daily flights from Leipzig to Hong Kong, four flights operating non-stop, and new direct weekend flights operating from Frankfurt to Atlanta and Chicago [152]. Services to the Emirate of Sharjah in the United Arab Emirates commenced in May 2010, with AeroLogic operating four days per week from Leipzig to Hong Kong to Sharjah and returning to Leipzig, as well as a weekly service from Frankfurt to Sharjah to Hong Kong and returning to Frankfurt [153].

Following the addition of a fifth B777-200LRF aircraft to the carrier's fleet in July 2010, the airline introduced twice-weekly weekday flights out of Leipzig to Shanghai's Pudong International Airport and Incheon International Airport in South Korea for DHL Express and a weekend flight to the same Asian points out of Lufthansa's Frankfurt hub, via Almaty, Kazakhstan [154].

In order to increase connectivity between Europe, the Middle East and Asia Pacific in October 2010 AeroLogic added three new flights: Hong-Kong to Leipzig, Leipzig to Bangkok, and Brussels to Bahrain [155]. An 'earlybird' connection from Hong Kong enabled DHL Express to offer a westbound next-day delivery service from one of the world's most important markets. The inclusion of the Bangkok stop on the airline's Leipzig/Singapore/Delhi route improved speed of delivery to the important Southeast Asian market. The new Brussels to Bahrain service added to the Leipzig to Bahrain connection and enhanced DHL's ability to serve a high-demand trade lane that connects both European and North American markets to the Middle East [156]. As at October 2010, AeroLogic's fleet of seven Boeing 777-200LRF aircraft was operating 107 weekly flights to 16 destinations in three major regions worldwide. In addition to the flights operated from its hub at Leipzig/Halle Airport, several flights also operated from Frankfurt, Brussels and East Midlands Airport in the United Kingdom. International destinations included: Bahrain and Sharjah in the Middle East and Almaty, and Delhi, Hong Kong, Seoul (Incheon International Airport), Shanghai (Pudong International Airport), and Singapore in the Far East [157].

In December 2010, AeroLogic added a third route to the Middle East. In addition to services to Bahrain and Sharjah, AeroLogic commenced services to Dubai as part of its Europe to Asia route plan. Further, in order to serve DHL Express' transatlantic next day delivery network, AeroLogic added weekday flights to DHL's main North America air hub in Cincinnati from Frankfurt. The flights were timed to feed directly into DHL's North American overnight express network and thereby assure overnight delivery capacity to the company's U.S. to Germany customers. In addition, AeroLogic also added a weekend direct flight from Leipzig to Cincinnati [158].

The airline's strategic intent was to expand their route network gradually, eventually operating direct services and connections to most of Asia's major metropolitan areas by 2011. In fact, following the delivery of the final four Boeing B777-200LRF freighter aircraft in 2010, the airline achieved its originally-planned network size and reach [157].

In March 2011, the Aerologic joint venture further enhanced connections between Frankfurt and the American south with the introduction of a weekly direct flight (Saturday) between Frankfurt and Houston. The northern Pakistan city of Lahore was also added to the Aerologic route network in March 2011 with the introduction of a weekly flight operating on Sundays from Frankfurt to Lahore and returning the following day [159]. AeroLogic commenced five weekly services to Bangalore, India on 11 October 2011, with the flights operating from Singapore and Bangkok to Bangalore and onto Leipzig [160]. On 19 April 2012, AeroLogic continued its network expansion when it commenced twice weekly direct services (Thursday/Sunday) on a new route for DHL from Bergamo Airport in Italy to Hong Kong [161].

In early 2014, Aerologic introduced new services to Dhaka, Bangaldesh and New York's John F. Kennedy International Airport on behalf of Lufthansa Cargo. In July 2014, the airline continued its route expansion with the introduction of new services from Frankfurt to Chennai Airport in India [162].

AeroLogic launched a new weekly service linking Frankfurt with the Turkmenistan capital Ashgabat and Hong Kong on the 29 March 2015 [163]. AeroLogic's route network expansion continued 
in 2016 with the introduction of a new weekly Frankfurt to Seattle service. This service was introduced in the summer schedule (effective 27 March) and operates from Frankfurt to Seattle then to Los Angeles. The flight returns from Los Angeles to Frankfurt [164].

Airline networks exhibit temporal attributes which means that the configuration of the network changes over time [165]. The AeroLogic route network has evolved over time with the addition of new cities being added to support the JV partners' requirements. AeroLogic's route network now currently comprises 20 destinations in Asia, Europe, the Middle East, and North America (Figure 4). As shown in Figure 3, originally AeroLogic provided services to Atlanta, Delhi, and Sharjah, however, these destinations are no longer being served by the airline. Additionally, the services introduced to New York's John F, Kennedy International Airport and Dhaka International Airport in 2014 are no longer operated by AeroLogic.

As noted earlier, during the week, Aerologic primarily operates services to Asia within the express network of DHL Express and, on the weekend, provides services for Lufthansa Cargo, respectively [123].

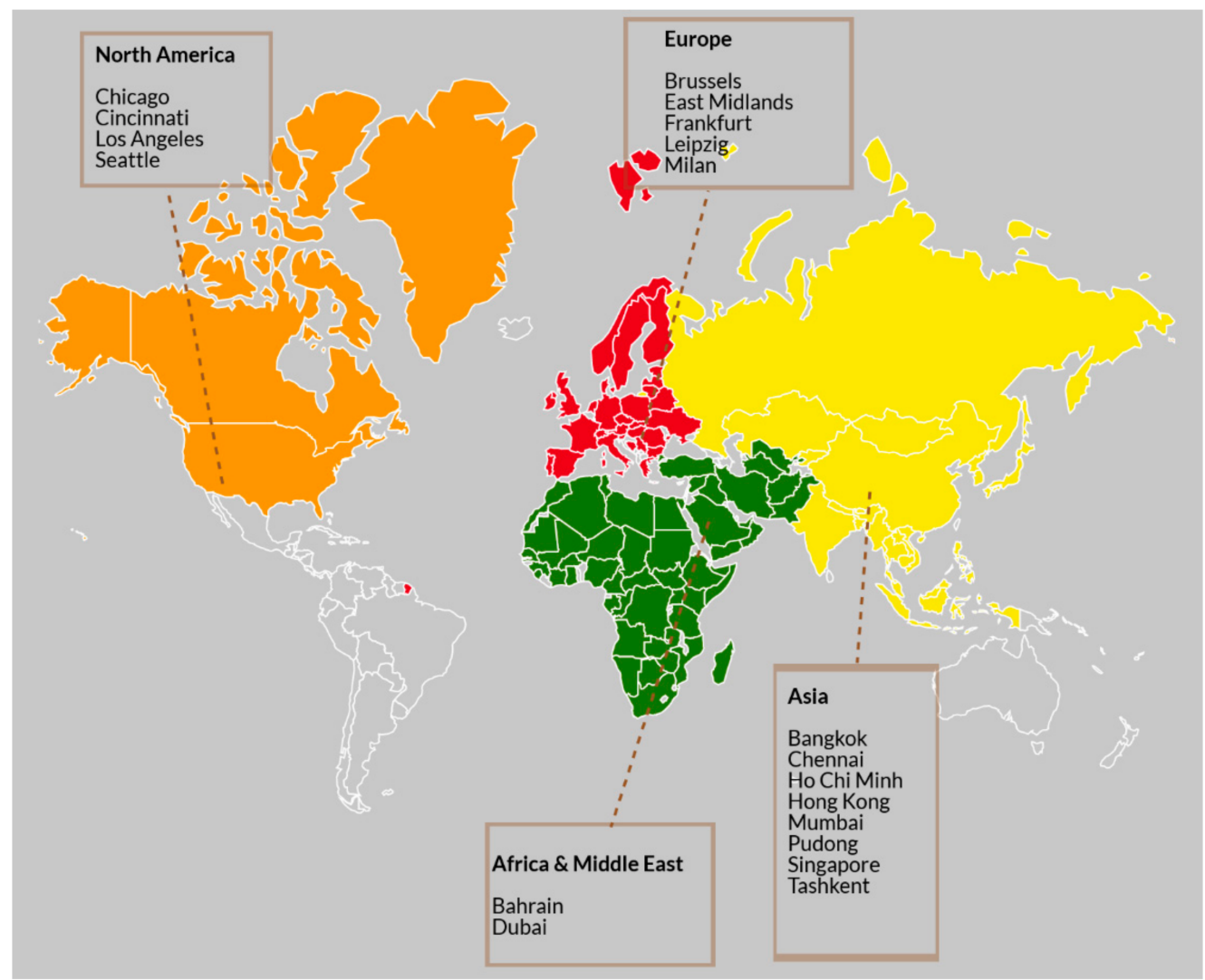

Figure 4. The AeroLogic route network: 2017. Airports Legend: BAH-Bahrain; BKK-Suvarnabhumi Airport; BOM-Mumbai; BRU-Brussels Airport; CVG-Cincinnati/Northern Kentucky International Airport DXB-Dubai; EMA-East Midlands, FRA-Frankfurt, HKG-Hong Kong; LAX-Los Angeles International Airport; LEJ-Leipzig/Halle Airport; MAA-Chennai Airport; MXP-Milan-Malpensa Airport; ORD-Chicago, PVG Pudong International Airport (Shanghai); SEA-Seattle-Tacoma International Airport; SGN-Tân Sơn Nhất International Airport (Vietnam); SIN-Singapore; TAS-Tashkent. Source: [166].

Combination airline passenger flights, particularly those operated by wide-bodied aircraft such as the Airbus A350-900XWB or the Boeing B777-300ER, can now offer around 25 tonnes of payload for cargo shipments. For a large full-service network carrier (FSNC) these have the advantage of frequent services to an extensive number of destinations [4,87]. There are, however, two key disadvantages with combination airlines: the timing of the flights is geared around passenger requirements. Notwithstanding, 
on long-haul intercontinental flights they may also suit cargo shippers [4] (p. 132). Additionally, some passenger destinations are not major air cargo markets and, therefore, will not attract much cargo $[4,120]$. As noted, the AeroLogic route network is customised to meet the JV partners' transportation requirements. Being an all-cargo airline, AeroLogic does not suffer from the disadvantages with combination airline services.

Furthermore, line-haul operators transport air cargo on an airport-to-airport basis and rely on international air freight forwarders to deal directly with shippers $[87,167]$. AeroLogic, in contrast, is not reliant upon air freight forwarders for its traffic.

It is also important to note that world air cargo traffic is concentrated on several key trade flows between regional centres of production and consumption. This concentration is especially pronounced in air cargo than for airline passenger flows, which are more diffuse in nature [168]. Inter-continental freighter routes are designed to link up the major centres of world trade. Such networks consist of long-haul flights to and from the airlines' major hub airport, where long-haul shipments are often broken down and uplifted on subsequent flights to their final destinations. The major types of freighter aircraft operated on long-haul inter-continental routes are the Boeing B777-200LRF, B747-400F, B747-8F, and MD11 aircraft [169]. AeroLogic's network, like the other dedicated air cargo carriers and the combination airlines operating freighter aircraft, follows the world's key trade lanes. As has been noted throughout this paper, the AeroLogic route network is customised to satisfy the two joint venture partners' requirements.

\subsubsection{AeroLogic's Product}

AeroLogic's product is the airport-to-airport transportation of the joint venture partners' air cargo traffic. This is quite a different strategy to other all-cargo airlines, for example, Luxembourg-based Cargolux Airlines offers a range of branded products that are targeted at discrete air cargo market segments: 'alive', 'classic', 'jumbo', 'power', 'hazmat', 'pharma', 'fresh', 'precious', 'select', and 'select +' [170]. Japan-based Nippon Cargo Airlines (NCA) has pursued a similar strategy to Cargolux and also offers a range of branded products targeted at discrete air cargo market segments. These products are 'NCA Express', 'NCA Freight', 'NCA Super Sensitive', NCA Sensitive', 'NCA Space', 'NCA Cool', 'NCA Art', 'NCA Vehicle', and 'NCA Pharmacare' [171].

\subsubsection{AeroLogic's Distribution Strategy}

AeroLogic is quite unique in the global air cargo industry in that it only transports cargoes on behalf of its two joint venture partners. In contrast, the other global all-cargo airlines, such as AirBridge Cargo Airlines, Cargolux, and Polar Air Cargo, source their air cargo traffic primarily from air freight forwarders. The combination airlines also principally source their air cargo business from freight forwarders. Consequently, more than $90 \%$ of global air cargo traffic is provided by air freight forwarders [120].

\subsubsection{AeroLogic's Staff}

At the time of the study, AeroLogic has two managing directors and around 350 staff, of which 260 are flight crew [115].

\subsubsection{AeroLogic's Strategy}

According to Porter [172,173], there are three types of competitive strategies: low cost, differentiation, and focus (niche). The low-cost leadership strategy endeavours to increase market through emphasizing the firm's low cost as compared to rivals [174]. In the global air cargo industry, United States-based dedicated all-cargo airline Polar Air has defined and implemented a low-cost strategy [175]. In a differentiation strategy, firms attempt to distinguish their products or services from others in the industry [174]. Cargolux, Lufthansa Cargo, and Nippon Cargo Airlines, for example, have introduced a range of differentiated products/services. Firms that adopt a focus strategy 
concentrate on a specific regional market or buyer group. The firm will aim to achieve either a low-cost advantage or a product differentiation advantage within a narrowly-defined market [174] (p. 60). Swiss World Cargo, for instance, follows a focus strategy [175].

With Porter's generic strategies, a firm can select a low-cost or differentiation strategy in a broad market perspective or combine a generic strategy with a focus on a market niche [176]. AeroLogic has followed a low-cost and focus or niche strategy by concentrating on its joint venture partner' discrete transportation and network requirements and reducing costs where possible, for example, by not having to market is services to freight forwarders.

\subsection{The Application of Porter's Five Forces Model to the AeroLogic Joint Venture}

The attractiveness of the global air cargo is determined by the following five essential competitive forces. The rivalry amongst the incumbent competitors (central driving force), threat of new entrants into the industry (limitations to market entry), bargaining power of buyers, bargaining power of suppliers, and the threat of substitute products or services [175].

\subsubsection{Intensity of Rivalry among Established Firms in the Global Air Cargo Market}

In the world air cargo industry, air cargo capacity is provided by combination passenger airlines, that is, airlines that carry passengers on the main deck and air cargo in their passenger aircraft lower lobe belly-holds and by dedicated all-cargo carriers, as well as the integrators, for example, FedEx and United Parcel Service (UPS) [177]. All-cargo services are operated by dedicated freighter aircraft with all the available capacity dedicated to air cargo transportation $[4,178]$. The intensity of competition between market incumbents is extremely high. This intensity in competition is due to a range of factors:

- There are many similar competitors active in the market. These carriers operate virtually the same aircraft type and their business models are comparable at a worldwide level [175]. Both the combination passenger airlines and the dedicated all-cargo airlines principally provide airport-to-airport services, and they source their traffic from air freight forwarders. In contrast, AeroLogic only acts as a linehaul carrier for its two JV partners, so its business model is quite different to the other incumbent airlines in the global air cargo industry.

- Air cargo capacity can only be introduced in quite large increments [175]. As previously noted, the major air cargo carrying airlines typically operate dedicated freighter aircraft, with airlines such as Cargolux, Nippon Cargo Airlines, and AirBridge Cargo Airlines operating fleets of Boeing B747-400 freighter or Boeing 747-8F freighters. These aircraft have a commercial payload of around 121.9 and 132.6 tonnes, respectively $[179,180]$. Other airlines, such as Etihad, Lufthansa Cargo, and Korean Air operate the Boeing B777-200LRF, which has a commercial payload of 103.7 tons [181]. Once again, AeroLogic has a competitive advantage in that its capacity is strategically deployed to satisfy the JV partners' requirements. Additionally, it only transports cargo on their behalf, so the size of the fleet is tailored to meet the volumes of cargoes generated by the two JV partners.

- The fixed assets that are required by actors to compete in the global air cargo industry, such as aircraft, air cargo terminals, and office buildings, can usually only grow in larger and fixed steps [175]. Aerologic, once again, enjoys an advantage as its fleet size and aircraft type is tailored to satisfy the JV partner requirements. As the airline only transports the JV partners' cargo on an airport-to-airport basis, it is not directly affected by the necessity for larger air cargo terminals as the JV partners take delivery of the cargoes directly from the aircraft. In contrast, both the combination and dedicated all-cargo airlines contract their cargo handling services to dedicated cargo handling companies [4] and, thus, adequate and efficient facilities are required to accommodate future growth and sustain the airline desired cargo service quality standards. The integrated carriers, such as FedEx and United Parcel Service (UPS) operate cargo terminals at their major and min-hubs, and contract cargo handling services at other airports. 
- The barriers to market exit in the air cargo industry are high $[175,182]$ due to the specialized means of production (aircraft), high fixed costs associated with the retirement of aircraft, and other government barriers [175]. Additionally, it can be quite difficult to sell large freighter aircraft [182].

\subsubsection{Barriers to Market Entry in the Global Air Cargo Industry}

The presence of market entry barriers restricts the number of firms competing in the global air cargo industry and, thus, influences the rivalry amongst the incumbent actors. There are four distinct types of legal entry barriers in the airline industry: airline ownership, airline operating licenses, route-specific air services rights, and perimeter rules at airports [183]. Furthermore, if new airlines enter the air cargo market, the competitive advantages of the incumbent carriers are immediately influenced. This is because the new entrant provides new additional air cargo carrying capacities in the existing market. This additional air cargo capacity typically diminishes the profit margins of all market participants [175]. When the market entry barriers are low, there is a greater threat to the incumbent airlines [184]. There are three other distinct entry barriers in the air cargo industry that are applicable for pure new dedicated cargo airlines, and not, however, for the additional air cargo capacity provided by the combination airlines.

- Existing incumbent all cargo airlines realize economies of scale by over proportionally decreasing the total cost whilst, at the same time, increasing their production capacity, that is, freight tonne kilometres (FTKs) performed;

- The incumbent carriers may have already attained high brand recognition, intense customer loyalty, or similar marketing targets. For the new entrant to compete in the market, then they must incur the costs for sales support, advertising, and other marketing initiatives; and

- Entry into the air cargo market requires substantial investment and capital. In terms of capital expenditure and costs incurred, the risk of a new cargo airline failing (sunk costs) presents a major hurdle for new market entrants [175] (p. 319).

In the global air transport industry, airport 'slots' are a classic barrier to market entry. In cases where airport slots continue to be awarded under the 'Grandfather Rights' principle, it would then be very difficult for new entrants to obtain access to attractively-timed slots at congested airports. However, the legalization of the so-called 'Secondary Slot Trading' does provide new entrants with the possibility of purchasing slots. If they do purchase them, however, they will still need to compete against incumbent airlines who obtained many, or all, of their slots for free [120] (p. 88). At the time of the current study, AeroLogic appeared to have not been affected by this issue.

Governmental policy is a major entry barrier [173]. In today's air cargo (and airline) industry there are stringent security regulations that can pose a barrier to market entry due to the associated costs [184]. Aerologic, like the combination airlines, the dedicated all-cargo airlines, and the integrated carriers, must comply with all government regulations.

AeroLogic is quite unique in the air cargo industry in that the airline is owned by two German-based firms (thus, there were no ownership issues), it has its own air operator certificate (AOC), and its primary hub is Leipzig/Halle Airport, which operates $24 \mathrm{~h}$ per day. Additionally, as has been noted previously, it only carries cargo on behalf of its two JV partners over a customized route network. Thus, the threat of a new entrant may be quite low for AeroLogic, but could be higher for Lufthansa Cargo, who provides air cargo services primarily using the belly-hold capacity of Lufthansa and Austrian Airlines passenger aircraft, as well as a fleet of Boeing B777-200LRF and Boeing MD11 freighter aircraft.

\subsubsection{Bargaining Power of Suppliers}

Within the air cargo industry, suppliers can pose a threat by raising their prices. As such, powerful suppliers could in this context reduce the profitability of firms competing in the industry, if they are not able to recoup cost increases through an increase in their pricing. The aircraft manufacturers and 
aviation fuel companies are powerful as these sectors are dominated by several firms, for example, Airbus and Boeing, and they are more concentrated than the airlines. Furthermore, their products delivered are vital for the consuming air cargo sector [175]. In the airline industry there are suppliers who either actually or potentially possess monopoly power. These include air traffic control (ATC) and airport services, with many carriers having to pay whatever ATC and airport services charges are levied upon them [120].

AeroLogic's two joint venture partners-DHL Express and Lufthansa Cargo AG-are very well established and successful firms that are highly regarded. Boeing and Lufthansa share a strong partnership of innovation and a tradition of launching new aircraft programs together [185]. DHL Express' major European hub is located at Leipzig/Halle Airport and the firm and the airport authority work closely together. Thus, AeroLogic is in a relatively strong position vis-à-vis its suppliers.

\subsubsection{Bargaining Power of Buyers}

Customers that have a high level of market power competition in the air cargo industry and they can place pressure on air cargo rates, whilst at the same time demanding higher quality or the extension of a carrier's existing product/serviced range [175]. As noted earlier, around $90 \%$ of world air cargo traffic is provided by freight forwarders [120]. These firms are powerful because they are often purchasing standardized or undifferentiated services, the costs associated with changing airlines is low, and the products/services provided by carriers are often easily exchanged or substituted [175].

Today, there is a relatively small number of international freight forwarders, such as DHL Global, Panalpina, and Schenker, who account for a major portion of the industry revenues and employees $[90,186]$. Certainly, there are still, and will continue to be, small- and mid-sized freight forwarding firms, as they can offer a level of specialisation or a combination of scope and flexibility that the large global operators cannot provide. Nonetheless, the global air cargo industry has never seen such a high degree of forwarder concentration as exists today. Given the large volumes of air cargo traffic that these large firms control, they can have considerable influence over an airline's routing decisions, and they are using that influence to develop cargo hubs at airports that they want [187] (p. 140).

Some freight forwarders have gone beyond merely booking cargo space on behalf of their customer on passenger and freighter services provided by the airlines. They are now offering shippers their own dedicated freighter services. Switzerland-based Panalpina Global Transport pioneered this trend in the 1990s with the introduction of a service from Luxembourg Airport to Huntsville, Alabama-the service was known as the 'Dixie Jet' [187] (p. 140). The actual flying for these services is performed on a charter basis from existing airlines, such as Cargolux and Atlas Air, though Panalpina controls the whole capacity of the aircraft [188].

Once again, as AeroLogic only transports cargoes on behalf of its two JV partners, it is not affected by the concentration of the freight forwarders nor their strategies to operate their own aircraft services, as in the case of Panalpina and its 'Dixie Air' service from Luxembourg to Huntsville, Alabama. This is another unique aspect of the AeroLogic business model.

\subsubsection{Threat of Substitute Products}

According to Oedekoven [175] (p. 320), substitution in the air cargo industry depends upon the specific market segment. Substitution is typically higher if the air cargo services being provided can be relatively easily switched from the original product/service to a substitute (low product loyalty). The possibility of buyers making a substitution are made greater if the incurred buyer switching costs are relatively low and if the air cargo rates are relatively high compared to the performance of the substitute product, for example, the slower speeds of trucks, which is considered acceptable to the buyer at the lower price [175]. The supply of air cargo capacity is influenced by the airline's available capacity, and competition from the surface-based transport modes, particularly maritime container transport [86]. Furthermore, improved trucking reliability and service quality, for instance, the ability of customers to track their consignments, lower theft/damage/pilferage rates, coupled 
with rates lower than airlines can offer, has put trucking in a position where it both competes with, and complements, air services [187] (p. 143). The rail mode is also emerging as a potential source of competition to air cargo, particularly between China and Europe [189], Thus, the surface transport modes can pose a competitive threat to air cargo-carrying airlines. The threat of the substitution of ground-based surface transport modes applies to both the combination airlines and the dedicated all-cargo carriers. In contrast, the threat of modal shift does not actually apply to Aerologic but does apply to both of its joint venture partners.

The air cargo industry has also been impacted by the use of electronic mail (e-mail) which has significantly reduced the market for the movement of urgent documents by the air cargo mode [120]. This trend influences the combination airlines, dedicated all-cargo carriers, and the integrated carriers or express carriers. Small packages of urgent documents were quite lucrative. AeroLogic is once again in a unique position in that it does not physically source air cargo consignments directly and, thus, it is not directly impacted by this trend. However, the two joint venture partners-DHL Express and Lufthansa Cargo AG—could potentially be impacted.

\subsection{The Strategic Benefits for the Two Partners from the AeroLogic Joint Venture}

As noted in Section 2, joint ventures are formed for a variety of strategic reasons (Table 4). Table 4 summarises the strategic benefits that the AeroLogic joint venture partnership has provided to the JV partners to date. Prior to the formation of the AeroLogic joint venture cargo airline, the two partners shared air cargo capacities on Lufthansa Cargo fleet of Boeing MD11 freighter aircraft. As can be observed in Table 4, the new airline is now providing greater strategic benefits for both partners. These include the joint sharing of risk, synergistic benefits, a highly efficient production platform, high daily aircraft utilisation, and the joint sharing of technical expertise and core competencies.

Table 4. The AeroLogic joint venture benefits.

\begin{tabular}{|c|c|}
\hline Joint Venture Benefit & AeroLogic Joint Venture \\
\hline Synergistic benefits & $\begin{array}{l}\text { Strategic and operational synergies are evident in the joint venture, for example, } \\
\text { the optimization of aircraft utilization through the joint operations (DHL Express on weekdays } \\
\text { and Lufthansa Cargo on weekends) }\end{array}$ \\
\hline $\begin{array}{l}\text { Enhancing the competitive } \\
\text { position in a market }\end{array}$ & $\begin{array}{l}\text { Prior to the JV, DHL Express was at a competitive disadvantage to its main competitors } \\
\text { FedEx and United Parcel Service (UPS) in that it did not have its own long-haul } \\
\text { intercontinental freighter network. Cooperation with Lufthansa Cargo has repaired that } \\
\text { deficiency, and has also provided DHL with the opportunity to utilize unused capacity } \\
\text { on long-haul flights for the carriage of conventional air cargo, a practice that the major } \\
\text { express operators rely on to some degree }\end{array}$ \\
\hline $\begin{array}{l}\text { Capturing competitive } \\
\text { advantage }\end{array}$ & $\begin{array}{l}\text { AeroLogic enjoys competitive advantages in that it only carries cargo on behalf of its partners, } \\
\text { has a low cost base, operates a modern and efficient fleet of Boeing B777-200LRF aircraft }\end{array}$ \\
\hline Access new markets & $\begin{array}{l}\text { For Lufthansa Cargo the JV provides a more direct means to participate in the } \\
\text { high-yielding air express market sector, while also being able to grow its long-haul } \\
\text { intercontinental network for the carriage of conventional air cargoes }\end{array}$ \\
\hline
\end{tabular}


Table 4. Cont.

\begin{tabular}{ll}
\hline \multicolumn{1}{c}{ Joint Venture Benefit } & AeroLogic Joint Venture \\
\hline $\begin{array}{l}\text { Overcome ownership } \\
\text { restrictions }\end{array}$ & This was not applicable as both JV partners are based in Germany \\
\hline $\begin{array}{l}\text { Increase efficiency } \\
\text { The airline is extremely lean and provides a highly-efficient production platform for the } \\
\text { two partners }\end{array}$ \\
\hline $\begin{array}{l}\text { Coordination of flight schedules } \\
\text { to reduce fleet size and take } \\
\text { advantage of offered capacity }\end{array}$ & $\begin{array}{l}\text { The flight schedules and aircraft fleet size has been optimised for both DHL Express and } \\
\text { Lufthansa Cargo. The aircraft operate for DHL during the week and for Lufthansa Cargo } \\
\text { on the weekend }\end{array}$ \\
\hline $\begin{array}{l}\text { Shared use of knowledge, } \\
\text { competencies and resources }\end{array}$ & $\begin{array}{l}\text { Both partners offer complementary technical skills, in-depth market knowledge and } \\
\text { resources and there is a very high level of cooperation between the partners }\end{array}$ \\
\hline $\begin{array}{l}\text { Joint procurement of fuel } \\
\text { and amenities }\end{array}$ & No details of this were available at the time of the present study \\
\hline $\begin{array}{l}\text { Cooperative advertising and } \\
\text { promotional campaigns }\end{array}$ & $\begin{array}{l}\text { The costs of advertising and marketing are not applicable as AeroLogic only carries } \\
\text { cargoes on behalf of the JV partners }\end{array}$ \\
\hline
\end{tabular}

As noted earlier, joint ventures are increasingly being viewed as an ideal strategic option to better compete in the global air cargo industry. Examples of these JVs include the ANA and Lufthansa JV on Japan-Europe routes, and the United Airlines and Lufthansa JV on Europe-USA routes. These JVs have principally focused on the joint sales of air cargo products and services, and optimizing the route networks of the joint venture partners. Other benefits include greater flexibility and time savings for customers and customer access to both partner's booking channels. The AeroLogic JV has provided similar benefits to both Lufthansa Cargo and DHL Express customers.

To date, the joint venture AeroLogic partnership between DHL Express and Lufthansa Cargo appears to have been extremely successful and is underpinned by a long-standing business relationship. As Table 4 has shown the AeroLogic JV has provided both firms with a range of strategic benefits that has underpinned their ability to compete in the general cargo and express cargo market segments. The two partners bring a range of complementary technical skills and resources to the JV, have very clearly identified objectives and performance criteria. There has been a long history of favourable past cooperation between the two partners. AeroLogic has provided both partners with strategic and operational synergies (Table 4), and the results of the JV have been reasonable [27], that is, the new airline has enabled both partners to achieve their strategic goals and leverage their long-standing business relationship.

\section{Conclusions}

This paper has examined, for the first time, the AeroLogic joint venture between DHL Express and Lufthansa Cargo AG. This is the global air cargo industry's largest and most intensive operating collaboration and partnership between an airline and a leading international express and logistics provider. Despite the increasing trend in joint ventures in the global air cargo industry, there has been very limited research undertaken on such initiatives. Thus, this study adds some valuable insights to the literature. The study was underpinned by a case study protocol and research framework that followed the recommendations of Yin [57] and applied Porter's Five Forces framework for the first time in assessing an air cargo joint venture airline. The case study has highlighted the strategic benefits that a joint venture cargo airline can offer. The study found that the AeroLogic joint venture cargo airline has a unique business model, and this has enabled the carrier, plus it two JV partners, to deliver and capture competitive advantage. A limitation of the current study was that key business performance, such as revenue and freight tonne kilometres (FTKs) were not available in the public domain. Should these data become available then a future study could compare the business performance of AeroLogic vis-à-vis its competitors.

In conclusion, the AeroLogic joint venture between DHL Express and Lufthansa Cargo AG has grown closer over time, ultimately culminating with the creation of the AeroLogic joint venture airline. 
This new airline has enabled both partners to enhance their competitive positions in the global air cargo industry. The airline operates a fleet of modern, highly-efficient Boeing B777-200LRF freighter aircraft from its key operational base at Leipzig/Halle Airport to the key global express and general air cargo markets. The airline's route network has changed over time and is customized to satisfy both the DHL Express and Lufthansa Cargo AG requirements.

Author Contributions: Glenn Baxter conceived the research idea and undertook the case study analysis. Glenn Baxter wrote the paper. Panarat Srisaeng analysed the case study results, edited the manuscript, and prepared the AeroLogic route network figures.

Conflicts of Interest: The authors declare no conflict of interest.

\section{References}

1. Royer, S.; Simons, R. Evolution of cooperation and dynamics of expectations-Implications of strategic alliances. Int. J. Strateg. Bus. Alliances 2009, 1, 73-88. [CrossRef]

2. Conway, P. Forced marriages. Airl. Bus. 1999, 15, 54-58.

3. Frampton, P. Where is air cargo heading? Insight 1997, 5, 22-27.

4. Morrell, P.S. Moving Boxes by Air: The Economics of International Cargo; Routledge: Abingdon, UK, 2016.

5. Zhang, A.; Hui, Y.V.; Leung, L.; Cheung, W.; Hui, Y.V. Air Cargo in Mainland China and Hong Kong; Ashgate Publishing: Aldershot, UK, 2004.

6. Geloso Grosso, M.; Shepherd, B. Liberalising Air Cargo Services in APEC, Working Paper October 2009. Available online: http:/ / citeseerx.ist.psu.edu/viewdoc/download?doi=10.1.1.493.9699\&rep=rep1\&type=pdf (accessed on 17 November 2017).

7. Zhang, A.; Lang, C.; Hui, Y.V.; Leung, L. Intermodal alliance and rivalry of transport chains: The air cargo market. Transp. Res. E 2007, 43, 234-246. [CrossRef]

8. Grönlund, P.; Skoog, R. Drivers of alliance formation in the air cargo business. In Strategic Management in the Aviation Industry; Delfmann, W., Baum, H., Auerbach, S., Albers, S., Eds.; Routledge: Abingdon, UK, 2016; pp. $473-487$.

9. Sowinski, L.L. Air cargo looks for 'Open Skies'. World Trade 2007, 20, 24-26.

10. Scott, W.R.; Davis, G.F. Organizations and Organizing: Rational, Natural and Open Systems Perspectives; Routledge: Abingdon, UK, 2016.

11. Ekin, A.C.; King, T.R. A struggling international partnership: TNK-BP joint venture. Int. J. Strateg. Bus. Alliances 2009, 1, 89-106. [CrossRef]

12. Ginter, P.M.; Duncan, W.J.; Swayne, L.E. The Strategic Management of Health Care Organizations, 7th ed.; Jossey-Bass: San Francisco, CA, USA, 2013.

13. Johnson, S.A.; Houston, M.B. A reexamination of the motives and gains in joint ventures. J. Financ. Quant. Anal. 2000, 35, 67-85. [CrossRef]

14. Shishido, Z.; Fukuda, M.; Umetani, M. Joint Venture Strategies: Design, Bargaining, and the Law; Edward Elgar Publishing: Cheltenham, UK, 2015.

15. Morais, L. Joint Ventures and EU Competition Law; Hart Publishing: Oxford, UK, 2013.

16. Hill, C.W.L.; Jones, G.R.; Schilling, M.A. Strategic Management: Theory: An Integrated Approach; Cengage Learning: Stamford, CT, USA, 2015.

17. Kazmi, A. Strategic Management and Business Policy, 3rd ed.; Tata-McGraw Hill Publishing: New Delhi, India, 2008.

18. Spulber, D.F. Economics and Management of Competitive Strategy; World Scientific Publishing: Singapore, 2009.

19. Yan, Y. International Joint Ventures in China: Ownership, Control and Performance; Macmillan Press: London, UK, 2000.

20. Hewitt, L. Joint Ventures, 3rd ed.; Sweet \& Maxwell: London, UK, 2005.

21. Harrison, J.S. Alternative to merger-Joint ventures and other strategies. Long Range Plan. 1987, $20,78-83$. [CrossRef]

22. Kogut, B. Knowledge, Options, and Institutions; Oxford University Press: Oxford, UK, 2008.

23. Yan, A.; Luo, Y. International Joint Ventures: Theory and Practice; Routledge: Abingdon, UK, 2015.

24. Beamish, P.W.; Lupton, N.C. Managing joint ventures. Acad. Manag. Perspect. 2009, 23, 75-94. [CrossRef]

25. Kukalis, S.; Jungemann, M. Strategic planning for a joint venture. Long Range Plan. 1995, 28, 4-57. [CrossRef] 
26. Hisrich, R.D.; Manimala, M.J.; Peters, M.P.; Shepherd, D.A. Entrepreneurship, 9th ed.; McGraw-Hill Education: New Delhi, India, 2012.

27. Hisrich, R.D.; Peters, M.P.; Shepherd, D.A. Entrepreneurship, 6th ed.; McGraw-Hill Professional: New York, NY, USA, 2005.

28. Harris, P.; McDonald, F. European Business and Marketing, 2nd ed.; SAGE Publications Ltd.: London, UK, 2004.

29. Ott, U.F. International Joint Ventures: An Interplay of Cooperative and Noncooperative Games under Incomplete Information; Palgrave-Macmillan: Basingstoke, UK, 2006.

30. Glaister, K.W.; Husan, R.; Buckley, P.J. Strategic Business Alliances: An Examination of the Core Dimensions; Edward Elgar Publishing: Cheltenham, UK, 2004.

31. Altinay, L.; Paraskevas, A.; Jang, S.C. Planning Research in Hospitality and Tourism, 2nd ed.; Routledge: Abingdon, UK, 2016.

32. Airlines International. Strategizing for Success. Available online: http:/ / airlines.iata.org/analysis/jointventures-help-airlines-deliver-choice-to-consumers (accessed on 27 January 2018).

33. Lufthansa Cargo. ANA and Lufthansa Cargo Successfully Launch Air Cargo Joint Venture. Available online: https: / / lufthansa-cargo.com/- /lhc-press-media-details-2014-page1-2 (accessed on 27 January 2018).

34. Cargo Airports \& Airline Services. United Airlines and Lufthansa Cargo Announce Cargo Joint Venture Agreement. Available online: http://www.caasint.com/single-post/2017/04/19/United-Airlines-andLufthansa-Cargo-Announce-Cargo-Joint-Venture-Agreement (accessed on 27 January 2018).

35. Abeyratne, R. Convention on International Civil Aviation: A Commentary; Springer International Publishing: Cham, Switzerland, 2014.

36. Oduntan, G. Sovereignty and Jurisdiction in Airspace and Outer Space: Legal Criteria for Spatial Delimitation; Routledge: Abingdon, UK, 2012.

37. Oum, T.H.; Yu, C. Winning Airlines: Productivity and Cost Competitiveness of the World's Major Airlines; Transportation, Research, Economics and Policy, Volume 6; Kluwer Academic Publishers: Norwell, MA, USA, 1998.

38. Rochat, P. The challenges of the future for the International Civil Aviation Organization. In Handbook of Airline Economics; Jenkins, D., Ed.; McGraw-Hill: New York, NY, USA, 1995; pp. 55-61.

39. Wang, Z. The impact of market liberalization on the formation of airline alliances. J. Air Transp. 2002, 7, $25-52$.

40. Doganis, R. The Airline Business, 2nd ed.; Routledge: Abingdon, UK, 2005.

41. Ustaömer, T.C.; Durmaz, V.; Lei, Z. The effect of joint ventures on airline competition: The case of American airlines, British airways and Iberia joint business. Procedia Soc. Behav. Sci. 2015, 210, 430-439. [CrossRef]

42. Wang, S.W. Do global airline alliances influence the passenger's purchase decision? J. Air Transp. Manag. 2014, 37, 53-59. [CrossRef]

43. Oum, T.H.; Park, J.H.; Kim, K.; Yu, C. The effect of horizontal alliances on firm productivity and profitability: Evidence from the global airline industry. J. Bus. Res. 2004, 57, 844-853. [CrossRef]

44. Scholz, A.B. Network Structures of Cargo Airlines: An Empirical and Modelling Approach; KIT Scientific Publishing: Karlsruhe, Germany, 2012.

45. Conway, P.; Kingsley-Jones, M. New era for Lufthansa-DHL. Airl. Bus. 2008, 24, 25.

46. Holloway, S. Straight and Level: Practical Airline Economics, 3rd ed.; Routledge: Abingdon, UK, 2016.

47. Air Cargo World. Cargo Alliances Await Technology. Available online: https:/ /aircargoworld.com/allposts / cargo-alliances-await-technology-6721/ (accessed on 19 November 2017).

48. Conway, P. Selective customers. Airl. Bus. 2003, 19, 62-64.

49. Conway, P. Team work. Airl. Bus. 2004, 20, 58-59.

50. Ahlstrom, D.; Bruton, G.D. International Management: Strategy and Culture in the Emerging World; South-Western Cengage Learning: Mason, OH, USA, 2010.

51. Krassadaki, E.; Matsatsinis, N.F. Decision aiding process in the frame of the strategic farm management. In Operational Research in Business and Economics, Proceedings of the 4th International Symposium and 26th National Conference on Operational Research, Chania, Greece, 4-6 June 2015; Grigoroudis, E., Doumpos, M., Eds.; Springer International Publishing: Cham, Switzerland, 2017; pp. 113-144.

52. Porter, M.E. Competitive Strategy: Techniques for Analyzing Industries and Competitors with a New Introduction; The Free Press: New York, NY, USA, 2008.

53. Rice, J.F. Adaption of Porter's Five Forces Model to Risk Management. Available online: http:/ / www.dtic. $\mathrm{mil} / \mathrm{dtic} / \mathrm{tr} /$ fulltext/u2/a523879.pdf (accessed on 30 January 2018). 
54. Porter, M.E. How competitive forces shape strategy? In Strategy: Seeking and Securing Competitive Advantage; Montgomery, C.A., Porter, M.E., Eds.; Harvard Business School Publishing: Moston, MA, USA; pp. 11-25.

55. Hill, C.W.L.; Jones, G.R. Essentials of Strategic Management, 2nd ed.; South-Western: Mason, OH, USA, 2009.

56. Dawes Farquhar, J. Case Study Research for Business; SAGE Publications: London, UK, 2012.

57. Yin, R.K. Case Study Research: Design and Methods, 6th ed.; SAGE Publications: Thousand Oaks, CA, USA, 2017.

58. Rahim, A.R.; Baksh, M.S. Case study method for new product development in engineer-to-order organisations. Work Study 2003, 52, 25-36. [CrossRef]

59. Yin, R.K. Case Study Research: Design and Methods, 4th ed.; SAGE Publications: Thousand Oaks, CA, USA, 2009.

60. Remenyi, D.; Williams, B.; Money, A.; Swartz, E. Doing Research in Business and Management: An Introduction to Process and Method; SAGE Publications: London, UK, 2010.

61. Ang, S.H. Research Design for Business E Management; SAGE Publications: London, UK, 2014.

62. Simons, H. Case Study Research in Practice; SAGE Publications: London, UK, 2009.

63. Ramon Gil-Garcia, J. Enacting Electronic Government Success: An Integrative Study of Government-Wide Websites, Organizational Capabilities, and Institutions; Springer Science-Business Media: New York, NY, USA, 2012.

64. Chester, L. A règulationist analysis of an industry sector using mixed research methods. In Handbook of Research Methods and Applications in Heterodox Economics; Lee, F.S., Cronin, B., Eds.; Edward Elgar Publishing: Cheltenham, UK, 2016; pp. 569-590.

65. Fitzgerald, T. Documents and documentary analysis. In Research Methods in Educational Leadership and Management, 3rd ed.; Briggs, A.N.R.J., Coleman, M., Morrison, M., Eds.; SAGE Publications: London, UK, 2012; pp. 296-308.

66. Love, P. Document analysis. In Research in the College Context: Approaches and Methods; Stage, F.K., Manning, K., Eds.; Brunner-Routledge: New York, NY, USA, 2003; pp. 83-96.

67. Scott, J.; Marshall, G. A Dictionary of Sociology, 3rd ed.; Oxford University Press: Oxford, UK, 2009.

68. Kridel, C. An Introduction to Documentary Research. Available online: http://www.aera.net/SIG013/ Research-Connections /Introduction-to-Documentary-Research (accessed on 30 January 2018).

69. Scott, J. A Matter of Record: Documentary Sources in Social Research; Polity Press: Cambridge, UK, 1990.

70. Scott, J. Documents, types of. In The SAGE Encyclopedia of Social Science Research Methods; Lewis-Beck, M.S., Bryman, A.E., Futing Liao, T., Eds.; SAGE Publications: Thousand Oaks, CA, USA, 2004; pp. 281-284.

71. O'Leary, Z. The Essential Guide to doing Research; SAGE Publications: London, UK, 2004.

72. Van Schoor, B. Fighting Corruption Collectively: How Successful Are Sector-Specific Coordinated Governance Initiatives in Curbing Corruption; Springer VS: Wiesbaden, Germany, 2017.

73. Morris, P.L. Triangulation. In The SAGE Encyclopedia of Communication Research Methods; Allen, M., Ed.; SAGE Publications: Thousand Oaks, CA, USA, 2017; pp. 1781-1783.

74. International Air Transport Association. Air Cargo: Enabling Global Trade. Available online: http:/ / www. iata.org/whatwedo/cargo/Pages/index.aspx (accessed on 22 November 2017).

75. Dahl, R.V. Freighter aircraft: Outlook uncertain. Aviat. Week Space Technol. 2001, 156, 55-58.

76. Dahl, R.V. Outlook improving for freighter aircraft. Aviat. Week Space Technol. 2003, 13, 58-61.

77. Dahl, R.V. Turbulence in the cargo arena. Aviat. Week Space Technol. 2010, 25, 82-86.

78. Belobaba, PP. Introduction and overview. In The Global Airline Industry, 2nd ed.; Belobaba, P., Odoni, A., Barnhart, C., Eds.; John Wiley \& Sons: Chichester, UK; pp. 1-18.

79. Airlines for America®. World Airlines Traffic and Capacity. Available online: http://airlines.org/dataset/ world-airlines-traffic-and-capacity / (accessed on 20 November 2017).

80. Kupfer, F.; Meersman, H.; Onghena, E.; Van de Voorde, E. World air cargo and merchandise trade. In Critical Issues in Air Transport Economics and Business; Macário, R., Van de Voorde, E., Eds.; Routledge: Abingdon, UK, 2011; pp. 98-111.

81. Leinbach, T.R.; Bowen, J.T. Air cargo services and the electronics industry in Southeast Asia. J. Econ. Geogr. 2004, 4, 299-321. [CrossRef]

82. Hui, G.W.L.; Hui, Y.V.; Zhang, A. Analyzing China's air cargo flows and data. J. Air Transp. Manag. 2004, 10, 125-135. [CrossRef]

83. Dahl, R.V. Expansion seen for air cargo industry. Aviat. Week Space Technol. 2001, 15, 59-64.

84. Yuan, X.M.; Low, J.M.W.; Tang, L.C. Roles of the airport and logistics services on the outcomes of an air cargo supply chain. Int. J. Prod. Econ. 2010, 127, 215-225. [CrossRef] 
85. Boeing Commercial Airplanes. World Air Cargo Forecast 2016-2017. Available online: http:/ /www.boeing.com/ resources/boeingdotcom/commercial/about-our-market/cargo-market-detail-wacf/download-report/assets/ pdfs/wacf.pdf (accessed on 20 November 2017).

86. Kupfer, F.; Kessels, R.; Goos, P.; Van de Voorde, E.; Verhetsel, A. The origin-destination airport choice for all-cargo aircraft operations in Europe. Transp. Res. E 2016, 87, 53-74. [CrossRef]

87. Doganis, R. Flying off Course: Airline Economics and Marketing, 4th ed.; Routledge: London, UK, 2010.

88. Air Cargo News. Top 25 Cargo Airlines: FedEx Maintains Top Spot But ABC and Qatar on the Up. Available online: http:/ / www.aircargonews.net/news/single-view/news/top-25-cargo-airlines-fedex-maintainstop-spot-but-abc-and-qatar-on-the-up.html (accessed on 22 November 2017).

89. Fox, M.C. Disintegrative Power Structures in Australian Export Airfreight Chains. Ph.D. Thesis, Griffith University, Brisbane, Australia, 2011.

90. Forster, P.; Regan, A. Electronic Integration in the air cargo industry: An information processing model of on-time performance. Transp. J. 2001, 40, 46-61.

91. Hallsworth, A.G.; Taylor, M.J. The transport sector and protected postal services: Regulating the activities of Purolator Courier Services in Canada. Transp. Policy 1999, 6, 159-168. [CrossRef]

92. Taylor, M.; Hallsworth, A. Power relations and market transformation in the transport sector: The example of the courier services industry. J. Transp. Geogr. 2000, 8, 237-247. [CrossRef]

93. Nelms, D.W. Holding its own. Air Transp. World 1996, 33, 151-154.

94. Lefer, H. Getting there first. Air Transp. World 1991, 28, 81-82.

95. Lobo, I.; Zairi, M. Competitive benchmarking in the air cargo industry: Part I. Benchmarking 1999, 6, 164-190. [CrossRef]

96. Eaton, J. The crazy economics of air freight. Intereconomics 1994, 29, 33-37. [CrossRef]

97. Mecham, M. DHL International extends worldwide network. Aviat. Week Space Technol. 1992, 137, 32.

98. Hill, L. Pushing the envelope. Air Transp. World 2003, 40, 57-60.

99. DHL Express. About Us: DHL. Logistics for the Connected Age. Available online: https:/ /www.logistics. dhl/au-en/home/about-us.html (accessed on 22 November 2017).

100. Deutsche Post DHL Group. Constantly Re-Inventing the Future of Logistics 2016 Annual Report. Available online: http://www.dpdhl.com/content/dam/dpdhl/Investors/Events/Reporting/2017/ FY2016/DPDHL_2016_Annual_Report.pdf (accessed on 22 November 2017).

101. Hill, L. Lufthansa chairman and CEO Jürgen Weber. Air Transp. World 2003, 40, 47-48.

102. Spinler, S.; Huchzermeier, A.; Kleindorfer, P.R. An options approach to enhance economic efficiency in a dyadic supply chain. In Cost Management in Supply Chains; Seuring, S., Goldbach, M., Eds.; Springer: Berlin/Heidelberg, Germany, 2002; pp. 350-360.

103. Bruch, H.; Sattelberger, T. The turnaround at Lufthansa: Learning from the change process. J. Chang. Manag. 2000, 1, 344-363. [CrossRef]

104. Nelms, D.W. Lufthansa cargo on its own. Air Transp. World 1996, 33, 68.

105. Lufthansa Cargo AG. About Us. Available online: https://lufthansa-cargo.com/meta/meta/company/ about-us (accessed on 22 November 2017).

106. Lufthansa Cargo AG. Facts \& Figures. Available online: https://lufthansa-cargo.com/documents/20184/29414/ Facts-Figures_30Mrz17_e.pdf/4975b3dc-0c90-8bbc-3e93-bfee8dbb582e (accessed on 22 November 2017).

107. Lufthansa Cargo AG. Hubs \& Service Center. Available online: https://lufthansa-cargo.com/network/ hubs-service-center (accessed on 22 November 2017).

108. Gallagher, T.L. Lufthansa, Austrian Airlines Create Joint Cargo Unit. Journal of Commerce Online, 27 May 2010. Available online: http:/ / www.joc.com/air-cargo/lufthansa-austrian-airlines-create-jointcargo-unit_20100527.html (accessed on 22 November 2017).

109. Lufthansa Group. Annua Report 2016. Available online: https:/ /irpages2.equitystory.com/download/companies / Lufthansa/Annual\%20Reports/DE0008232125-JA-2016-EQ-E-00.pdf (accessed on 22 November 2017).

110. Parker, J.; Krause, K.S. Towards the world crown. Traffic World 2000, 262, 11-12.

111. Turney, R. Maybe mega. Air Cargo World 2004, 94, 14-16.

112. Putzger, I. Gateway in the making. J. Commer. 2007, 8, 32-33.

113. Flottau, J.; Taverna, M.A. Air Logic. Aviat. Week Space Technol. 2004, 160, 47.

114. Siegmund, H. AeroLogic High Wide \& Handsome, Air Cargo News, Volume 8, No. 65. Available online: http:/ / www.aircargonews.com/090619/FT090619.html (accessed on 21 November 2017). 
115. AeroLogic GMBH. Profile: AeroLogic has Established Itself as a Powerful Cargo Airline. Available online: https:/ / www.aerologic.aero/profile (accessed on 22 November 2017).

116. Karp, A. Lufthansa, DHL to Launch AeroLogic Joint Venture Next Year, Air Transport World Online, 29 January 2008. Available online: http://atwonline.com/aircraft-amp-engines/lufthansa-dhl-launchaerologic-cargo-jv-next-year (accessed on 22 November 2017).

117. Whyte, R.; Lohmann, G. Airline business models. In Air Transport Management: An International Perspective; Budd, L., Ison, S., Eds.; Routledge: Abingdon, UK, 2017; pp. 107-121.

118. Cook, G.N.; Billig, B. Airline Operations and Management: A Management Textbook; Routledge: Abingdon, UK, 2017.

119. Moorman, R.W. Choosing the fleet. Air Cargo World 2007, 97, 32-37.

120. Shaw, S. Airline Marketing and Management, 7th ed.; Ashgate Publishing: Farnham, UK, 2011.

121. Shaw, S. Effective Air Freight Marketing; Hyperion Books: London, UK, 1993.

122. Hatton, R. Complexities of air cargo vis-à-vis air finance: The economics of wide-body freighter aircraft. In Handbook of Airline, Finance; Butler, G.F., Keller, M.R., Eds.; McGraw-Hill: New York, NY, USA, 1999; pp. 535-542.

123. AeroLogic GMBH. Profile: The Most Modern Air Freighter Fleet in Europe. Available online: https: / / www.aerologic.aero/fleet (accessed on 22 November 2017).

124. Norris, G. Kings of cargo. Flight Int. 2006, 169, 36-38.

125. Clark, J.S.; Kirwan, K.D. 777 Freighter: Efficiency for long-haul operators. AERO Mag. 2009, 2, 5-9.

126. Conway, P. Decline of the jumbo? Airl. Bus. 2005, 21, 62-63.

127. Flottau, J. Team spirit. Aviat. Week Space Technol. 2008, 168, 43.

128. AeroLogic GmbH. AeroLogic Ready for Take-off with Low Emission Aircraft. Available online: http:// parcelindustry.com/article-1213-Aerologic-Ready-for-Take-Off-with-Low-Emission-Aircraft.html (accessed on 22 November 2017).

129. Barnard, B. Lufhansa, DHL Launch Joint Cargo Airline. Journal of Commerce Online, 19 June 2009. Available online: http:/ / www.joc.com/air-cargo/lufthansa-dhl-launch-joint-cargo-airline_20090619.html (accessed on 20 November 2017).

130. Barnard, B. AeroLogic Takes Delivery of First Freighter. Journal of Commerce Online, 14 May 2009. Available online: https:/ / www.joc.com/air-cargo/aerologic-takes-delivery-first-freighter_20090514.html (accessed on 20 November 2017).

131. Baxter, G.; Kourousis, K. Temperature controlled aircraft unit load devices: The technological response to growing global air cargo cool chain requirements. J. Technol. Manag. Innov. 2015, 10, 157-172. [CrossRef]

132. Clark, P. Buying the Big Jets: Fleet Planning for Airlines, 3rd ed.; Routledge: Abingdon, UK, 2017.

133. Lennane, A. Cargo calling. Airfinance J. 2008, 309, 23.

134. Turney, R. Virtual air. Air Cargo World 2008, 98, 13-15.

135. Aero News Network. Lufthansa Cargo/DHL Express JV AeroLogic to Operate Boeing 777 Freighters. Available online: http:/ / www.aero-news.net/getmorefromann.cfm?do=main.textpost\&id=6e3b2981-80ea411b-aead-4ea87445d98d (accessed on 22 November 2017).

136. Segal, S. Boeing delivers first 777F to AeroLogic. Airfinance Journal, 10 May 2009.

137. Barnard, B. Eastern flow. J. Commer. 2008, 9, 22-26.

138. Turney, R. Choosing Leipzig. Air Cargo World 2004, 94, 2-14.

139. Field, A.M. Jump-starting the Trabant. J. Commer. 2008, 9, 32-36.

140. Shippers Today. DHL Opens New European Hub in Leipzig. Available online: http://info.hktdc.com/ shippers/vol31_4/vol31_4_air04.htm (accessed on 22 November 2017).

141. Power, A. Cities for a Small Continent: International Handbook of City Recovery; Policy Press: Bristol, UK, 2016.

142. Urquhart, D. Leipzig-Halle leapfrogs into the big time. Payload Asia 2009, 25, 32-33.

143. Leipzig/Halle Airport. Cargo: Infrastructure. Available online: https://www.leipzig-halle-airport.de/en/ business-and-partners / cargo/infrastructure-182.html (accessed on 22 November 2017).

144. Leipzig/Halle Airport. Leipzig/Halle Airport: Driving Force in a Region in the Centre of Europe. Available online: https:/ / www.leipzig-halle-airport.de/mediapool/company_profile_leipzig_halle_airport_july_ 2013.pdf (accessed on 22 November 2017).

145. Putzger, I. Lufthansa's zero-risk growth for 2009. Air Cargo World 2008, 98, 24-27.

146. Leipzig/Halle Airport. Leipzig/Halle Airport: Europe's Dynamic Cargo Hub. Available online: https: / / www.leipzig-halle-airport.de/mediapool/cargo-praesentation.pdf (accessed on 22 November 2017). 
147. Otto, A. Reflecting the prospects of an air cargo carrier. In Strategic Management in the Aviation Industry; Delfmann, W., Baum, H., Auerbach, S., Albers, S., Eds.; Routledge: Abingdon, UK, 2017; pp. 451-472.

148. Cento, A. The Airline Industry: Challenges in the 21st Century; Springer: Berlin/Heidelberg, Germany, 2009.

149. Holloway, S. Changing Planes: A Strategic Management Perspective on an Industry in Transition, Volume Two: Strategic Choice, Implementation, and Outcome; Ashgate Publishing: Aldershot, UK, 1998.

150. AeroLogic GMBH. The Customised AeroLogic Network; AeroLogic: Leipzig, Germany, 2009.

151. Yun, J. AeroLogic Ups Flights to Changi, Procurement Asia, 30 July 2009. Available online: http:/ / www. procurement-online.com/news/14284 (accessed on 5 January 2014).

152. Barnard, B. AeroLogic Adds Flights to U.S., Hong Kong. Journal of Commerce Online, 18 January 2010. Available online: http://www.joc.com/air-cargo/aerologic-adds-flights-us-hong-kong_20100118.html (accessed on 22 November 2017).

153. Gallagher, T.L. Aerologic Expands into Middle East. Journal of Commerce Online, 18 May 2010. Available online: http:/ / www.joc.com/air-cargo/aerologic-expands-middle-east_20100518.html (accessed on 22 November 2017).

154. Hastings, P. DHL Expanding Its Mainland Footprint. Cargonews Asia, 12 July 2010. Available online: http:/ / www. cargonewsasia.com/(F(mDf0Jo-2BTLE--sWIc-zqgEbsK1luJi-i3oC-NM64lgtBfzQdyJxJQsnaWnWCrxOCulvCfJygE158bMa0b8TBTA5f49Ld22a7p0Xamx5-w1)) / secured/article.aspx?id=15\&article=23181 (accessed on 9 October 2013).

155. AeroLogic GmbH. AeroLogic Expands Network with Two New Routes to Asia and the U.S., AeroLogic Press Release 14 January 2010. Available online: http:/ / www.aerologic.aero/pressdetail?pressID=21 (accessed on 7 July 2013).

156. DHL Express. DHL Expands Express Air Route System Between Europe, Asia Pacific and Middle East, Press Release 19 October 2010. Available online: http:/ / www.dhl.com/en/press/releases/releases_2010/ express /191010.html (accessed on 20 November 2017).

157. AeroLogic GmbH. AeroLogic Expands Network and Increases Connectivity Between Europe, the Middle East and Asia Pacific, AeroLogic Press Release 19 October 2010. Available online: http:/ / www.aerologic. aero/pressdetail?pressID=24 (accessed on 7 July 2013).

158. AeroLogic GmbH. AeroLogic Operates in Full Swing, AeroLogic Press Release 9 December 2010. Available online: http: / / www.aerologic.aero/pressdetail?pressID=25 (accessed on 7 July 2013).

159. Lufthansa Cargo A.G. Lufthansa Cargo Serving New Destinations in Summer Timetable, Press Release March 2011. Available online: https://lufthansa-cargo.com/-/lhc-press-media-details-2011-page3-8 (accessed on 23 November 2017).

160. Peri, K. Menzies Wins DHL as New Customer at Bangalore Airport. Available online: http:/ / www.menziesaviation. $\mathrm{com} /$ item/detail/p/3/id/263/ref/Menzies-wins-DHL-as-new-customer-at-Banglaore-Airport (accessed on 19 November 2013).

161. Finelli, M. Aerologic Fly Bergamo-Hong Kong for DHL, 22 March, 2012. Available online: http:/ /www.flightglobal. com/airspace/blogs / flybolognairport/archive/2012/03/22/aerologic-fly-bergamo-hong-kong-for-dhl.aspx (accessed on 30 October 2013).

162. Siegmund, H. AeroLogic Turns Five. Available online: https://www.cargoforwarder.eu/2014/06/23/ aerologic-turns-five/ (accessed on 24 November 2017).

163. Lufthansa Cargo AG. New Services to Ashgabat Successfully Started. Available online: https://lufthansacargo.com/- /new-services-to-ashgabat-successfully-started?redirect=https $\% 3 \mathrm{~A} \% 2 \mathrm{~F} \% 2 \mathrm{Flufthansa-cargo.com} \%$ 2Fsearchresult\%3Fp_p_id\%3D3\%26p_p_lifecycle\%3D0\%26p_p_state\%3Dnormal\%26p_p_mode\%3Dview\%26p_ p_col_id\%3Dcolumn-1\%26p_p_col_pos\%3D1\%26p_p_col_count\%3D2\%26_3_keywords\%3DAeroLogic\%26_3_ struts_action\%3D\%252Fsearch\%252Fsearch\&inheritRedirect=true (accessed on 23 November 2017).

164. Lufthansa Cargo AG. Lufthansa Cargo Route Network Grows. Available online: https://lufthansa-cargo. com/- / lufthansa-cargo-route-network-grows (accessed on 23 November 2017).

165. Wu, C.L. Airline Operations and Delay Management: Insights from Airline Economics, Networks, and Strategic Schedule Planning; Routledge: Abingdon, UK, 2016.

166. AeroLogic GmbH. The Customised AeroLogic Network; AeroLogic: Leipzig, Germany, 2017. Available online: https: / / www.aerologic.aero/network (accessed on 23 November 2017).

167. Button, K.J.; Stough, R. Air Transport Networks: Theory and Policy Implications; Edward Elgar Publishing: Cheltenham, UK, 2000. 
168. Zhang, A.; Zhang, Y. Issues on liberalization of air cargo services in aviation. J. Air Transp. Manag. 2002, 8, 275-287. [CrossRef]

169. Baxter, G. AERO2426 Air Cargo Management and Operations Topic 4 Learning Guide: Airline Air Cargo Hubs and Route Networks; RMIT University: Melbourne, Australia, 2015.

170. Cargolux Airlines S.A. Product Overview. Available online: http://www.cargolux.com/our-expertise/ product-overview (accessed on 26 January 2018).

171. Nippon Cargo Airlines. Products and Services. Available online: http://www.nca.aero/e/service/ transport/index.html (accessed on 26 January 2018).

172. Porter, M.E. What is strategy? In On Competition; Porter, M.E., Ed.; Harvard Business School Publishing: Boston, MA, USA, 1998; pp. 39-73.

173. Porter, M.E. Competitive Strategy: Techniques for Analyzing Industries and Competitors; The Free Press: New York, NY, USA, 1980.

174. Daft, R.L.; Murphy, J.; Willmott, H. Organization Theory and Design; Cengage Learning EMEA: Andover, UK, 2010.

175. Oedekoven, M. Air cargo management. In Introduction to Aviation Management; Wald, A., Fay, C., Gleich, R., Eds.; LIT Verlag: Münster, Germany, 2010; pp. 310-327.

176. Israeli, A. Generic strategies. In International Encyclopedia of Hospitality Management, 2nd ed.; Pizam, A., Ed.; Butterworth-Heinemann: Kidlington, UK, 2010; pp. 281-282.

177. Baxter, G.S.; Bardell, N.S. Can the renewed interest in ultra-long-range passenger flights be satisfied by the current generation of civil aircraft? Aviation 2017, 21, 42-54. [CrossRef]

178. Coyle, J.J.; Novack, R.A.; Gibson, B.; Bardi, E.J. Transportation: A Supply Chain Perspective, 7th ed.; South-Western Cengage Learning: Mason, OH, USA, 2011.

179. Boeing Commercial Airplanes. 747-400 Airplane Characteristics for Airport Planning, Document Number D6-58326-1. Available online: http:/ / www.boeing.com/resources/boeingdotcom/commercial/airports / acaps /747_4.pdf (accessed on 31 January 2018).

180. Boeing Commercial Airplanes. 747-8 Airplane Characteristics for Airport Planning, Document Number D6-58326-3. Available online: http://www.boeing.com/assets/pdf/commercial/airports/acaps/747_8.pdf (accessed on 31 January 2018).

181. Boeing Commercial Airplanes. 777-200LR/-300ER/-Freighter Airplane Characteristics for Airport Planning, Document Number D6-58329-2. Available online: http://www.boeing.com/assets/pdf/commercial/ airports/acaps/777_2lr3er.pdf (accessed on 31 January 2018).

182. Panibratov, A. Russian Multinationals: From Regional Supremacy to Global Lead; Routledge: Abingdon, UK, 2012.

183. Knorr, A.; Arndt, A. Most low-cost airlines fail(ed): Why did Southwest Airlines prosper? In Competition Versus Predation in Aviation Markets: A Survey of Experience in North America, Europe and Australia; Forsyth, P., Gillen, D.W., Mayer, O.G., Niemeier, H.M., Eds.; Routledge: Abingdon, UK, 2018; pp. 145-172.

184. Flouris, T.G.; Oswald, S.L. Designing and Executing Strategy in Aviation Management; Ashgate Publishing: Aldershot, UK, 2006.

185. Boeing Commercial Airplanes. Lufthansa Group. Available online: http://www.boeing.com/commercial/ customers/lufthansa/lufthansa-will-be-launch-customer-for-new-boeing-777x.page (accessed on 31 January 2018).

186. Conway, P. Dominant force. Airl. Bus. 2005, 21, 52-54.

187. Tretheway, M.W.; Andriulaitis, R.J. Airport competition for freight. In Airport Competition: The European Experience; Forsyth, P., Gillen, D., Müller, J., Niemeier, H.M., Eds.; Routledge: Abingdon, UK, 2016; pp. 137-150.

188. Cottrill, K. High hopes. Traffic World 1998, 256, 28-33.

189. The Economist. New Rail Routes between China and Europe will Change Trade Patterns. Available online: https://www.economist.com/news/business/21728981-new-silk-railroad-will-challenge-airlinesand-shipping-firms-new-rail-routes-between-china (accessed on 31 January 2018).

(C) 2018 by the authors. Licensee MDPI, Basel, Switzerland. This article is an open access article distributed under the terms and conditions of the Creative Commons Attribution (CC BY) license (http:/ / creativecommons.org/licenses/by/4.0/). 